\title{
Role of Estrogen Receptor $\alpha$ and $\beta$ in Preserving Hippocampal Function during Aging
}

\author{
Xiaoxia Han, ${ }^{1}$ Kristina K. Aenlle, ${ }^{2}$ Linda A. Bean, ${ }^{1}$ Asha Rani, ${ }^{1}$ Susan L. Semple-Rowland, ${ }^{1}$ Ashok Kumar, ${ }^{1}$ \\ and Thomas C. Foster ${ }^{1}$ \\ ${ }^{1}$ Department of Neuroscience, McKnight Brain Institute, University of Florida, Gainesville, Florida 32610-0244, and 2Department of Veterans Affairs \\ Medical Center, Geriatric Research, Education and Clinical Center, Miami, Florida 33125
}

The expression of the ER $\alpha$ and $\operatorname{ER} \beta$ estrogen receptors in the hippocampus may be important in the etiology of age-related cognitive decline. To examine the role of $\operatorname{ER} \alpha$ and ER $\beta$ in regulating transcription and learning, ovariectomized wild-type (WT) and ER $\alpha$ and ER $\beta$ knockout (KO) mice were used. Hippocampal gene transcription in young ER $\alpha$ KO mice was similar to WT mice $6 \mathrm{~h}$ after a single estradiol treatment. In middle-age ER $\alpha \mathrm{KO}$ mice, hormone deprivation was associated with a decrease in the expression of select genes associated with the blood-brain barrier; cyclic estradiol treatment increased transcription of these select genes and improved learning in these mice. In contrast to $\mathrm{ER} \alpha \mathrm{KO}$ mice, $\mathrm{ER} \beta \mathrm{KO}$ mice exhibited a basal hippocampal gene profile similar to WT mice treated with estradiol and, in the absence of estradiol treatment, young and middle-age ER $\beta$ KO mice exhibited preserved learning on the water maze. The preserved memory performance of middle-age ER $\beta$ KO mice could be reversed by lentiviral delivery of ER $\beta$ to the hippocampus. These results suggest that one function of $\operatorname{ER} \beta$ is to regulate $\operatorname{ER} \alpha$-mediated transcription in the hippocampus. This model is supported by our observations that knockout of $\operatorname{ER} \beta$ under conditions of low estradiol allowed ER $\alpha$-mediated transcription. As estradiol levels increased in the absence of $\mathrm{ER} \alpha$, we observed that other mechanisms, likely including $\mathrm{ER} \beta$, regulated transcription and maintained hippocampaldependent memory. Thus, our results indicate that $\operatorname{ER} \alpha$ and $\operatorname{ER} \beta$ interact with hormone levels to regulate transcription involved in maintaining hippocampal function during aging.

\section{Introduction}

The DNA binding domains of $\alpha$ and $\beta$ estrogen receptors (ERs) are highly homologous (Katzenellenbogen and Korach, 1997; Enmark and Gustafsson, 1999); however, estradiolinduced transcriptional activity differs because of divergence of the ligand binding domain and disparities in the recruitment of coregulators (Nilsson et al., 2001; Harrington et al., 2003). Under low levels of estradiol, $\mathrm{ER} \alpha$ transcriptional activity is greater than that of ER $\beta$ (Barkhem et al., 1998; Pettersson et al., 2000). Moreover, ER $\beta$ can heterodimerize with $\mathrm{ER} \alpha$ to inhibit $\mathrm{ER} \alpha$-mediated gene expression (Hall and McDonnell, 1999; Pettersson et al., 2000; A. Gottfried-Blackmore et al., 2007; Gonzales et al., 2008), indicating that regulation of gene expression is dependent upon the ratio of $\mathrm{ER} \alpha$ to $\mathrm{ER} \beta$ and the level of estradiol (Foster, 2012).

Estradiol is neurotrophic (Gould et al., 1990; Woolley et al., 1990; Woolley and McEwen, 1992; Choi et al., 2003; Akama and

Received Oct. 19, 2012; revised Nov. 21, 2012; accepted Nov. 26, 2012.

Author contributions: T.C.F. designed research; X.H., K.K.A., L.A.B., A.R., A.K., and T.C.F. performed research; T.C.F. analyzed data; S.L.S.-R. and T.C.F. wrote the paper.

This work was supported by National Institutes of Health Grants AG014979, AG037984, and AG036800, and the Evelyn F. McKnight Brain Research Foundation. We thank Irina Madorsky, Jose Herrera, Gina Prado, Paul Huang, and Katrina Velez for technical assistance.

The authors declare no competing financial interests.

Correspondence should be addressed to Dr. Thomas C. Foster, Department of Neuroscience, McKnight Brain Institute, University of Florida, P0 Box 100244, Gainesville, FL 32610-0244. E-mail: Foster1@mbi.ufl.edu.

DOI:10.1523/JNEUROSCI.4937-12.2013

Copyright $\odot 2013$ the authors $\quad 0270-6474 / 13 / 332671-13 \$ 15.00 / 0$
McEwen, 2003; Kretz et al., 2004; Rune and Frotscher, 2005; Jelks et al., 2007) and neuroprotective (Nilsen and Diaz Brinton, 2003; Dubal et al., 2006; Garcia-Segura et al., 2006; Aenlle and Foster, 2010), functions that likely underlie the ability of estradiol to preserve cognitive function during aging (Foster, 2012). Interestingly, estradiol's effects on cognitive aging are reduced in aging women (Sherwin, 2006) and rodents (Gibbs, 2000; Markham et al., 2002; Markowska and Savonenko, 2002; Foster et al., 2003; Sherwin, 2006; Bimonte-Nelson et al., 2006; Daniel et al., 2006; Talboom et al., 2008), and temporally correlated with altered hippocampal expression of $\mathrm{ER} \alpha$ and $\mathrm{ER} \beta$ (Tohgi et al., 1995; Adams et al., 2002; Mehra et al., 2005; Sharma and Thakur, 2006; Thakur and Sharma, 2007; Ishunina et al., 2007; Bohacek and Daniel, 2009). Thus, an age-related change in the ratio of $\mathrm{ER} \alpha /$ $\mathrm{ER} \beta$ expression in the hippocampus may contribute to the reduced ability of estradiol treatment to alter gene expression (Aenlle and Foster, 2010) and the reduction in the efficacy of hormone therapy to ameliorate memory loss that often accompanies advanced age (Foster, 2012).

In this study, we used ovariectomized ER $\alpha \mathrm{KO}$ and ER $\beta \mathrm{KO}$ female mice to investigate how selective loss of one receptor subtype affects behavior and gene expression profiles in aging mice. Our results are consistent with the idea that, under low estradiol conditions associated with female aging, activation of ER $\alpha$ helps to regulate hippocampal gene expression and function. If ER $\alpha$ levels are reduced, our data suggest that $\operatorname{ER} \beta$ can compensate to maintain hippocampal function provided that estradiol levels are increased. 


\section{Materials and Methods}

Mice. $\mathrm{ER} \alpha^{-1-}(\mathrm{ER} \alpha \mathrm{KO})$ (Lubahn et al., 1993) and $\operatorname{ER} \beta^{-1-}$ (ER $\left.\beta K O\right)$ (Krege et al., 1998) mice were generated from heterozygous mouse colonies. The genotypes of the mice were screened using PCR amplification as previously described (Lubahn et al., 1993; Krege et al., 1998). Wild-type (WT) littermates produced from the $\mathrm{ER} \alpha \mathrm{KO}$ and $\mathrm{ER} \beta \mathrm{KO}$ breeding colonies were combined into one WT group. Animals were housed 3-5 per cage and maintained on 12:12 light/dark cycle (lights on at 6:00 A.M.). All procedures involving animal subjects were reviewed and approved by the Institutional Animal Care and Use Committee at the University of Florida and were performed in accordance with guidelines established by the U.S. Public Health Service Policy on Humane Care and Use of Laboratory Animals.

Figure 1 shows the timeline for injections, behavioral training, and tissue collection for each study, starting from the time of surgery. Young mice (WT: $n=27$; ER $\alpha \mathrm{KO}: n=21$; ER $\beta$ KO: $n=25$ ) were 4 months at the time of surgery. For examination of gene transcription profiles, young mice were ovariectomized, and $10 \mathrm{~d}$ after surgery were treated with a single injection of oil or estradiol. The hippocampi of these mice were collected $6 \mathrm{~h}$ later (Fig. 1A). The experimental groups included WT-EB $(n=7)$, WT-oil $(n=7)$, ER $\alpha \mathrm{KO}-\mathrm{EB}(n=5)$, ER $\alpha \mathrm{KO}$-oil $(n=5)$, $\mathrm{ER} \beta \mathrm{KO}$-EB $(n=7)$, and ER $\beta \mathrm{KO}$-oil $(n=5)$. To determine whether knockout of either ER $\alpha$ or ER $\beta$ influences hippocampal function in young mice, $\operatorname{ER} \alpha \mathrm{KO}(n=11), \operatorname{ER} \beta \mathrm{KO}(n=13)$, and WT $(n=13)$ mice were ovariectomized and their performance on the water maze task was examined, starting $10 \mathrm{~d}$ after surgery and was repeated 4 weeks later (Fig. 1B).

Middle-age mice (WT: $n=15$; ER $\alpha$ KO: $n=23$; ER $\beta$ KO: $n=52$ ) were 13-14 months old at the time of surgery. To determine whether ER $\alpha$ and ER $\beta$ contribute to estradiol effects on behavior and gene expression during middle age, $\mathrm{ER} \alpha \mathrm{KO}$ and $\mathrm{ER} \beta \mathrm{KO}$ mice were treated with either oil or estradiol. Treatments were initiated 1 week after surgery and were delivered on two contiguous days of a $5 \mathrm{~d}$ cycle in accord with our previously published work (Aenlle et al., 2009) (Fig. 1C). The experimental groups included $\mathrm{ER} \alpha \mathrm{KO}$-oil $(n=7), \mathrm{ER} \alpha \mathrm{KO}-\mathrm{EB}(n=8), \mathrm{ER} \beta \mathrm{KO}$-oil $(n=12)$, $\operatorname{ER} \beta \operatorname{KO}-\mathrm{EB}(n=11)$, WT-oil $(n=15)$, and WT-EB $(n=14)$ littermates. Twenty-four hours after the last injection, hippocampi were collected for gene arrays and uterine tissue was collected and weighed. To determine whether expression of ER $\beta$ disrupts spatial learning, lentivirus encoding $\operatorname{ER} \beta$ and GFP $(n=12)$ or GFP alone $(n=11)$ was bilaterally injected in the hippocampus of middle-age ER $\beta \mathrm{KO}$ mice at the time of ovariectomy, and behavior was examined starting 5 weeks later (Fig. 1D).

Surgeries. Female mice (4 months and 13-14 months) were anesthetized ( $2 \mathrm{mg}$ ketamine and $0.2 \mathrm{mg}$ xylazine per $20 \mathrm{~g}$ of body weight), and the ovaries were removed through a small abdominal midline incision. All mice received ad libitum access to food (Purina mouse chow) and water until the surgery, after which time they were placed on caseinbased chow (Cincinnati Lab Supply) that has lower levels of phytoestrogens compared with soy-based chow.

Hippocampal lentiviral injections. To determine whether the behavioral changes observed in middle-age ER $\beta \mathrm{KO}$ mice could be attributed to the absence of ER $\beta$, female ER $\beta K O$ (13-14 months) were ovariectomized and either pFin-EF1 $\alpha$-GFP-CMV-(FLAG)ER $\beta$-WPRE (ER $\beta$-FLAG) or pFIN-EF1 $\alpha$-GFP-WPRE (GFP) lentivirus $\left(2 \times 10^{12}\right.$ transducing Us/ $\left.\mu \mathrm{l}\right)$ was injected bilaterally into the hippocampus $1.0 \mu \mathrm{l}$ per side. Techniques for hippocampal injection of virus have previously been published (Foster et al., 2008; Zeier et al., 2009; Lee et al., 2012).
Estradiol treatments. Estradiol (17 $\beta$-estradiol benzoate, EB) (Sigma) was dissolved $(0.1 \mathrm{mg} / \mathrm{ml})$ in light mineral oil (Fisher Scientific) and was injected subcutaneously $(5 \mu \mathrm{g})$ at the nape of the neck. In rodents, plasma estradiol levels rapidly increased within 1-4 h after a single EB injection (Woolley and McEwen, 1993; Sohrabji et al., 1994), and EBinduced transcriptional changes follow a similar time course (Hammer et al., 1986; Priest et al., 1995; Sohrabji et al., 1995; Too et al., 1999; Aenlle et al., 2009; Aenlle and Foster, 2010). Therefore, for young animals, a single injection was used to examine transcription $6 \mathrm{~h}$ after treatment. The dose and time point were selected to maintain consistency with our previous studies examining the effects of estradiol on transcription (Aenlle et al., 2009; Aenlle and Foster, 2010).

To examine the effects of estradiol on behavior and transcription in middle-age mice, injections $(5 \mu \mathrm{g})$ were delivered on two contiguous days of a $5 \mathrm{~d}$ cycle and were initiated 1 week after surgeries in accord with our previously published work (Aenlle et al., 2009). Previous work indicated that repeated injections using these delivery parameters can improve spatial learning and memory in mice (Frick et al., 2002; Xu and Zhang, 2006; Walf et al., 2008; Aenlle et al., 2009).

Water maze. Behavioral studies involving the water maze were performed in accord with our previously published work (Foster et al., 2008; Aenlle et al., 2009). All mice were first trained on the cue discrimination version of the Morris swim task using four training blocks, with three trials per block. Spatial training was initiated either 3 or $6 \mathrm{~d}$ after the completion of the cue discrimination training, using methods that have been previously described (Foster et al., 2008; Aenlle et al., 2009). Briefly, spatial training was performed over a period of three consecutive days and consisted of four training blocks with three trials per block per day. The penultimate trial on days 2 and 3 consisted of a probe trial that served as an index of learning. The probe trial was performed by placing the mouse in the tank for $1 \mathrm{~min}$ without the platform and recording both the time the animal spent in each quadrant of the tank and the number of times the animal crossed the location in the tank from which the platform had been removed. The spatial discrimination index was computed using the formula $(\mathrm{G}-\mathrm{O}) /(\mathrm{G}+\mathrm{O})$, where $\mathrm{G}$ and $\mathrm{O}$ represent the percentage of time spent in the goal quadrant and quadrant opposite the goal, respectively.

RNA isolation and microarray analyses. Mice were anesthetized with $\mathrm{CO}_{2}$ and decapitated. The brain was quickly removed and placed in 
ice-cold artificial CSF. Both hippocampi were removed, frozen in liquid nitrogen, and stored at $-80^{\circ} \mathrm{C}$. Total RNA was isolated from each sample using a Qiagen RNeasy Lipid Tissue Mini Kit (Qiagen). RNA concentration was determined using a spectrophotometer, and a subset of samples was examined using an Agilent 2100 Bioanalyzer (Agilent Technologies) to assess sample quality. Microarray hybridization was performed by the Interdisciplinary Center for Biotechnology Research Microarray Core, University of Florida, following the manufacturer's protocol.

The first study examined the transcriptional response in young (4 months) mice treated with estradiol. Mice were killed $6 \mathrm{~h}$ after injection of either estradiol or oil, and hippocampi were prepared for gene transcript analyses using Affymetrix Mouse 4302.0 arrays (one array per mouse) (Blalock et al., 2003; Aenlle and Foster, 2010). Normalization and computation of gene expression values were performed using dChip (Li and Wong, 2001). The detection of signal (presence/absence) was determined by MAS Version 5.0 (Affymetrix). The number of present calls for each probe was determined across all arrays using the criterion that at least $80 \%$ of the chips within any single group (genotype and treatment) had to exhibit a present call for that probe to be included in subsequent analyses. Using this criterion, 24,111 probes were selected for further analyses. Affymetrix GeneChip Mouse Gene 1.0 ST Arrays (one array per mouse) were used for examination of transcription in middleage mice, after cyclic injections of either estradiol or oil.

Quantitative PCR. Quantitative PCRs were performed using Gene Expression Assay Mix TaqMan Universal PCR Master Mix $(2 \times)$, and a 7300 Real-Time PCR System with SDS Software Version 1.3.1 analysis software (Applied Biosystems). The PCR primers were designed to produce short amplified products that crossed exon-exon junctions and minimized amplification of off-target sequences (ESR1: exons 4 and 5, $56 \mathrm{bp}$, NP_031982.1; ESR2 variant 1: exons 9 and 10, 69 bp, NP_997590.1; ESR2 variant 2: exons 8 and 9, 69 bp, NP_034287.3; BTG2: exons 1 and 2, 102 bp, NP_031596.1; NPAS4: exons 4 and 5, 62 bp, NP_705781.1). Each sample was run in triplicate, and the values were normalized to GAPDH according to our previously described methods (Aenlle et al., 2009; Aenlle and Foster, 2010).

Construction of lentiviral vectors. The lentiviral vector pFIN-WPRE backbone contained a $2 \times 250$ bp core chicken $\beta$-globin HS4 insulator sequence in the $3^{\prime}$ LTR and a woodchuck hepatitis post-transcriptional regulatory element (WPRE) to enhance transgene expression (SempleRowland et al., 2007). A dual-promoter vector was constructed by inserting transgenes encoding GFP and FLAG tagged ER $\beta$ into the multiple cloning site of the pFIN backbone. The transgenes were arranged headto-tail so that transcription for both proceeded in the same direction and the transgenes shared the same polyadenylation site located in dl.R region of the $3^{\prime}$ LTR. The EF1 $\alpha$ (elongation factor-1 $\alpha$ ) promoter was amplified using PCR ( $5^{\prime}$ (NotI), ATT GCG GCC GCT TTG GAG CTA A; 5' (NotI), TTA GCG GCC GCC ACG ACA CCT GAA AT); and was ligated into pFIN-WPRE at the NotI site to create pFIN-EF1 $\alpha$-WPRE. GFP was amplified using PCR (5' (NheI), GCA GCT AGC CGC CAC CAT GAG CAA; 5' (NheI-MluI-BsiWI), AAT GCT AGC ACG CGT CGT ACG AGA GGC CTC AGT CAG); and was ligated into pFIN-EF1 $\alpha$ WPRE at the NheI site to create pFIN-EF $1 \alpha$-GFP-WPRE. The cytomegalovirus (CMV) promoter was amplified using PCR (5' (BsiWI), ATA CGT ACG TAG TTC ATA GCC CAT ATA TGG; 5' (MluI-AsiSI-PacI), TAT ACG CGT GCG ATC GCT TAA TTA AGT AAG CAG TGG GTT CTC TAG T); and was ligated into pFIN-EF1 $\alpha$-GFP-WPRE using the BsiWI and MluI sites to create pFIN-EF $1 \alpha$-GFP-CMV-WPRE. Finally, the open-reading frame encoding human FLAG-tagged ER $\beta$ was amplified from pcDNA4/TO-FLAG:hERb (kind gift from Dr. Chegini) using primers that introduced PacI sites on the $5^{\prime}$ - and $3^{\prime}$-ends of the coding region (5'-ATA TTA ATT AAA AAC TTA AGC TTA CCG CCA TG; 5'-ATA TTA ATT AAC CCT CTA GAT CAC TGA GAC). The PCR product (1679 bp) was then ligated into pFIN-EF1 $\alpha$-GFP-CMV-WPRE at the PacI site to produce pFin-EF $1 \alpha$-GFP-CMV-(FLAG)ER $\beta$-WPRE. The integrity of FLAG-ER $\beta$ in the final vector was verified by sequencing.

The functionality of (FLAG)ER $\beta$ was confirmed using previously published methods (Foster et al., 2008). The ability of the receptor to respond to estradiol was examined by cotransfecting HEKT293 cells with pFinEF $1 \alpha$-GFP-CMV-(FLAG)ER $\beta$-WPRE and ERE-TA-SEAP reporter plas- mids and measuring changes in secreted placental alkaline phosphatase after exposure to estradiol. The bicistronic lentiviral vector encoding GFP and (FLAG)ER $\beta$ was packaged into lentivirus using a three plasmid packaging system as previously described (Semple-Rowland et al., 2007). Viral titers were estimated using a Lenti-X qRT-PCR kit (Millipore Bioscience Research Reagents) and typically averaged $2 \times 10^{12}$ viral genomes per milliliters.

Statistical analyses. For measures of behavior and uterine weight, ANOVAs were used to establish main effects and interactions. Follow-up ANOVAs and Fisher's protected least significant difference post hoc comparisons $(p<0.05)$ were used to identify significant comparisons. Onetailed Student's $t$ tests $(p<0.05)$ were used to determine whether the discrimination indices, calculated from the quadrant search behavior (Foster et al., 2003), were different from that expected by chance (i.e., a discrimination index $=0)$. Two-tailed $t$ tests $(p<0.025)$ were used to identify differentially expressed probes according to previously published work (Aenlle et al., 2009; Aenlle and Foster, 2010).

\section{Results}

\section{Gene expression in the hippocampus of young adult ER $\alpha \mathrm{KO}$ and ER $\beta$ KO mice}

We have previously shown that a single $5 \mu$ g estradiol injection administered to young mice produces robust changes in hippocampal gene expression $6 \mathrm{~h}$ after treatment (Aenlle and Foster, 2010). To examine the role of $\operatorname{ER} \alpha$ and $\operatorname{ER} \beta$ in regulating hippocampal gene expression, we examined the gene expression profiles of 4-month-old ER $\alpha \mathrm{KO}$ and $\mathrm{ER} \beta \mathrm{KO}$ female mice that were ovariectomized and subsequently treated with estradiol $10 \mathrm{~d}$ after surgery and compared them with control animals that were treated with oil vehicle (Fig. 1A).

Analysis of differential gene expression after estradiol treatment revealed that there were 1295 probes that were differentially expressed between WT-EB and WT-oil-treated mice (Fig. 2A). Within the set of 1295 probes, 585 (45\%) of these increased in expression and $710(55 \%)$ decreased in expression. Only five probes showed $\mathrm{a} \geq 2$-fold increase in expression. ER $\alpha$ and ER $\beta$ $\mathrm{KO}$ mice were less responsive to acute estradiol treatment than WT animals as measured by changes in gene expression. The expression levels of 268 and 195 probes in the ER $\alpha \mathrm{KO}-\mathrm{EB}$ and ER $\beta$ KO-EB treatment groups, respectively, were altered compared genotype-matched oil treatment controls. None of the gene expression changes in the estradiol-treated $\mathrm{ER} \alpha \mathrm{KO}$ and $\mathrm{ER} \beta \mathrm{KO}$ mice were $\geq 2$-fold. These results indicate that, compared with genotype-matched and oil-treated animals, young $\mathrm{ER} \alpha$ and $\mathrm{ER} \beta \mathrm{KO}$ mice are less responsive to estradiol treatment than WT mice.

To determine whether knockout of either the $\operatorname{ER} \alpha$ or the $\operatorname{ER} \beta$ receptor alters gene expression, we examined gene expression profiles in $\mathrm{ER} \alpha \mathrm{KO}$ and $\mathrm{ER} \beta \mathrm{KO}$ animals treated with oil or estradiol and compared them with the gene expression profiles of WT-oil-treated mice (Fig. $2 B$ ). ER $\alpha$ KO mice treated with oil exhibited very few differences in gene expression ( 183 probes) compared with the WT-oil controls. The expression levels of five $\mathrm{ER} \alpha \mathrm{KO}$-oil-treated probes increased $>2$-fold, three of which represented the ER $\alpha$ gene (ESR1 Affymetrix probes: 1453145_at, 1460591_at, and 1457877_at). This result suggests that functional knockout of the $\operatorname{ER} \alpha$, resulting from insertion of a neomycin cassette, induces a compensatory increase in ESR1 transcription to counter loss of $\mathrm{ER} \alpha$ receptor activity. Comparison of ER $\alpha$ KO-EB-treated mice with WT-oil revealed 2368 differentially expressed probes. The level of expression of the majority of these probes increased in ER $\alpha \mathrm{KO}$-EB-treated mice (1583 increasing and 785 decreasing) (Fig. 2B). Of the probes that showed an increase in expression, 72 increased at least twofold 
and included the three probes for ESR1. No probe decreased by $\geq 2$-fold. Collectively, these data show that $\mathrm{ER} \alpha \mathrm{KO}$ mice are responsive to estradiol treatments, a result that supports the idea that $\mathrm{ER} \beta$ can compensate for the loss of ER $\alpha$ (Fugger et al., 2000; Foster et al., 2008).

Unlike $\mathrm{ER} \alpha \mathrm{KO}$ mice, the expression levels of 1125 probes exhibited changes in ER $\beta K O$ mice treated with oil compared with WT-oil controls (Fig. 2B). The majority of these probes $(912,81 \%)$ showed an increase in expression in ER $\beta \mathrm{KO}$-oiltreated animals. Moreover, the expression of 196 of these probes increased $>2$-fold, including the probe for the $\operatorname{ER} \beta$ gene (ESR2: 1426103_a_at); however, ER $\beta$ probe was not analyzed further because the number of present calls for this probe across all groups did not reach the criterion. Of the 213 probes that showed a decrease in expression, none showed a decrease $\geq 2$ fold. Comparisons of ER $\beta K O-E B$ mice with WT-oil controls revealed that 1142 probes were differentially expressed in the ER $\beta$ KO-EB mice (698 increasing and 444 decreasing; Fig. 2B). Of these, the expression of 3 probes increased and one decreased with magnitudes $>2$-fold. Thus, in contrast to $\mathrm{ER} \alpha \mathrm{KO}$ mice whose basal gene expression levels were similar to WT animals, ER $\beta K O$ mice exhibit a considerable shift in basal gene expression, a shift that may reflect removal of the inhibitory influences of $\mathrm{ER} \beta$ on $\mathrm{ER} \alpha$-mediated transcription (Pettersson et al., 2000; Williams et al., 2008).

To visualize the changes in basal and estradiol-induced gene expression, the mean expression levels for probes in each group were normalized to the average expression levels of the corresponding probes in WT-oil-treated mice. WT probes whose expression significantly increased in response to estradiol treatment were sorted by the magnitude of their increases, and the percentage change values for the top 100 probes were plotted with the normalized measures for ER $\alpha \mathrm{KO}$ (Fig. $2 C$ ) or ER $\beta \mathrm{KO}$ (Fig. $2 D$ ) mice. The levels of basal gene expression in $\mathrm{ER} \alpha \mathrm{KO}$-oil mice were slightly higher than those in WT-oil mice (i.e., 100\%). Estradiol treatment of $\mathrm{ER} \alpha \mathrm{KO}$ mice further increased gene expression so that the levels of gene expression were similar to WT-EB (Fig. $2 C)$. Gene expression levels in ER $\beta K O$ mice were always higher than those in WT-oil mice regardless of treatment (Fig. 2D) and were similar to those found in WT-EB mice. Indeed, in contrast to the estradiol-mediated increase in gene expression in WT and $\mathrm{ER} \alpha \mathrm{KO}$ mice, a paired $t$ test of the normalized values revealed that expression of these genes was reduced $\left[t_{(99)}=4.94, p<\right.$ $0.0001)$ in ER $\beta$ KO-EB $(155 \pm 2 \%$ of WT-oil $)$ compared with ER $\beta$ KO-oil mice (172 $\pm 6 \%$ of WT-oil). Our analyses of estradiol-induced changes in hippocampal gene expression are consistent with reports of gene expression changes in other tissues responsive to estradiol (Lindberg et al., 2003; O'Lone et al., 2007) and suggest that, under normal conditions, ER $\beta$ inhibits $\mathrm{ER} \alpha$-mediated transcription. The observation that ER $\beta \mathrm{KO}$-oil mice exhibit a transcription profile similar to WT-EB mice is consistent with this idea.
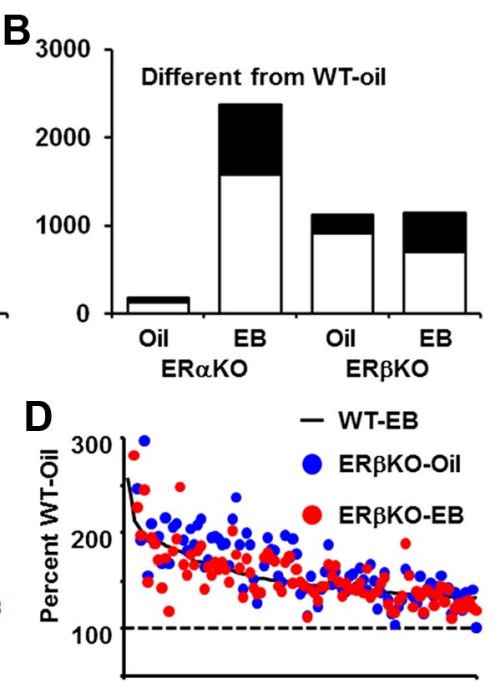

Figure 2. Gene expression in young ( 4 months) WT and ERKO mice, $6 \mathrm{~h}$ after estradiol (WT $=7$, ER $\alpha K 0=5$, ER $\beta K 0=7$ ) or treated mice exhibited a relatively large shift in basal gene expression, with the majority of probes (81\%) showing increases in ploir expression in ER $\alpha K 0$-oil (C, blue circles) and ER $\alpha \mathrm{KO}$-EB (C, red circles) and ER $\beta K 0$-oil (D, blue

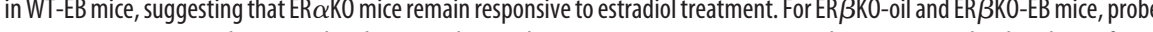
expression was greater than WT-oil and appeared to track expression in WT-EB mice, results suggesting that knockout of ER $\beta$ permits expression of estradiol-sensitive genes in the absence of estradiol treatment.

To determine whether basal gene expression patterns in $\mathrm{ER} \alpha \mathrm{KO}$ and ER $\beta \mathrm{KO}$ mice influence hippocampal function, 4-month-old ER $\alpha \mathrm{KO}, \mathrm{ER} \beta \mathrm{KO}$, and WT mice were ovariectomized and their performances on a cue discrimination water maze task were examined $10 \mathrm{~d}$ after surgery. A repeated-measures ANOVA indicated that there was a decrease in distance to find the escape platform $\left[F_{(3,102)}=7.73, p<0.0001\right]$ over the four blocks of training, in the absence of a genotype difference (Fig. $3 A$ ). Examination of spatial discrimination over $3 \mathrm{~d}$ of training (session 1) indicated that there was a decrease in the escape path length $\left[F_{(2,68)}=11.62, p<0.0001\right]$ in the absence of a genotype difference (Fig. 3B). Repeated-measures ANOVAs of the probe trial data for the penultimate trial on days 2 and 3 indicated that there was no training effect and no genotype difference for the discrimination index scores or platform crossings (Fig. 3C, D). However, examination of training effects in each group indicated that ER $\beta K O$ mice did show a training effect for platform crossing $\left[F_{(1,12)}=5.44, p<0.05\right]$. To determine whether any group used a spatial search strategy, we compared the discrimination index scores relative to chance (score $=0$ ) performance using onetailed $t$ tests. Only ER $\beta K O$ mice exhibited acquisition of a spatial search strategy, with a discrimination index score above chance $(p<0.05)$ at the end of training on day 3 (Fig. 3C).

To determine whether the duration of hormone deprivation resulting from ovariectomy influences spatial learning, ovariectomized $\mathrm{ER} \alpha \mathrm{KO}$, ER $\beta \mathrm{KO}$, and WT mice were retested on the spatial version of the water maze 1 month after the first training session (session 2) using a new spatial location. Similar to the 

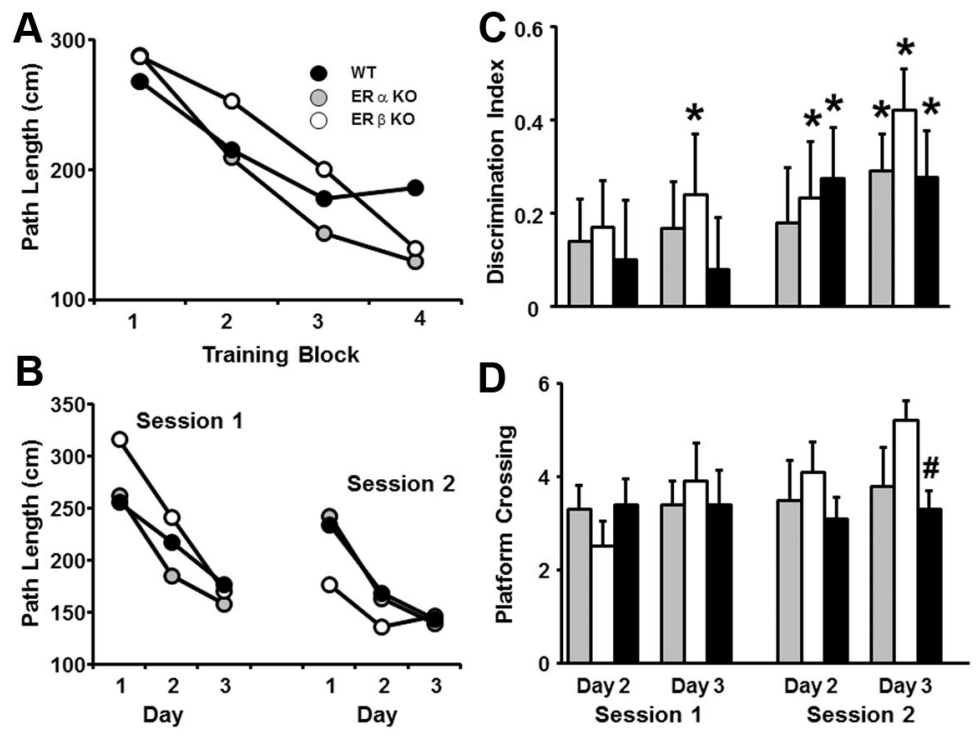

Figure 3. Water maze performance of young ERKO and WT mice. $\boldsymbol{A}$, Mean path length to reach an escape platform over four training blocks (three trials per block) for WT (filled circles, $n=13$ ), ER $\alpha$ KO (gray circles, $n=11$ ), and ER $\beta K 0$ (open circles, $n=$ 13). A decrease in path length was observed in the absence of a genotype effect. $\boldsymbol{B}$, Mean path length to reach an escape platform during spatial training. Training was provided in two sessions, starting $13 \mathrm{~d}$ after ovariectomy (session 1) and again $30 \mathrm{~d}$ after ovariectomy (session 2). For each session, a decrease in path length was observed in the absence of a genotype effect. C, Discrimination index calculated from performance on probe trials for WT (filled bars), ERKO (gray bars), and ERKO (open bars). Probe trials were delivered as the penultimate trial on days 2 and 3 for each session. *Performance above chance and acquisition of a spatial search strategy. D, Platform crossing calculated from probe trial performance. "Significant difference between ER $\beta$ KO and WT mice.

previous learning data, an effect of training $\left[F_{(2,68)}=13.85, p<\right.$ $0.0001]$ on the escape path length was observed in the absence of a genotype difference (Fig. 3B), and no training or genotype differences were observed for the discrimination index scores and platform crossing. Examination of training effects in each genotype indicated that only the ER $\beta \mathrm{KO}$ mice showed a training effect for the discrimination index $\left[F_{(1,12)}=6.88, p<0.05\right]$ and for platform crossings $\left[F_{(1,12)}=8.08, p<0.05\right]$. Unlike the earlier tests in which only the ER $\beta K O$ acquired a spatial search strategy, one-tailed $t$ tests indicated that ER $\beta \mathrm{KO}$ and WT mice acquired a spatial search strategy by day 2 and all groups performed above chance for day 3 (Fig. 3C). Finally, examination of platform crossings indicated that there was a significant genotype effect on day $3\left[F_{(2,34)}=3.38, p<0.05\right]$. Post hoc tests indicated that the performances of ER $\beta \mathrm{KO}$ mice were better than those observed in WT mice and that ER $\beta K O$ mice exhibited a tendency $(p=0.085)$ to cross the platform more often than $\mathrm{ER} \alpha \mathrm{KO}$ mice. Together, these results indicate that ER $\beta \mathrm{KO}$ mice exhibited a modest, although significant, improvement in spatial learning compared with the other groups.

\section{ER $\alpha$ and ER $\beta$ influences on hippocampal function and gene expression in middle-age mice}

The effect of ovariectomy and estradiol treatment on hippocampal function varies across the life span (Foster, 2005). Previous work indicates that cyclic injections of estradiol can improve spatial learning and memory in mice, including middle-age mice (Frick et al., 2002; Gresack and Frick, 2006; Xu and Zhang, 2006; Walf et al., 2008; Aenlle et al., 2009). To determine whether ER $\alpha$ and $\operatorname{ER} \beta$ contribute to the observed effects of estradiol on behavior and gene expression during middle age, $\mathrm{ER} \alpha \mathrm{KO}$ and $\mathrm{ER} \beta \mathrm{KO}$ mice were ovariectomized at 13 months of age, treated with oil or estradiol, behaviorally tested, and killed to examine hippocampal and uterine tissues (Fig. 1C). Uterine weight across experimental groups exhibited an interaction of genotype and treatment $\left[F_{(2,61)}=5.1, p<0.01\right]$ (Fig. 4). Post hoc analyses confirmed that estradiol treatment increased uterine weight in WT and $\mathrm{ER} \beta \mathrm{KO}$ mice, but not in $\mathrm{ER} \alpha \mathrm{KO}$ mice (Lindberg et al., 2002). Furthermore, uterine weight was higher in ER $\beta \mathrm{KO}$-oil mice compared with ER $\alpha \mathrm{KO}$-oil and WToil mice. These results are consistent with the view that $\mathrm{ER} \alpha$ induces uterine growth in response to estradiol treatment and that $\mathrm{ER} \beta$ normally dampens $\mathrm{ER} \alpha$ activity (i.e., knockout of $\mathrm{ER} \beta$ promotes uterine growth in the absence of estradiol treatment).

Cue discrimination task training was performed during week 5 after surgery, $48 \mathrm{~h}$ after the fifth series of cyclic injections of estradiol or oil (Fig. 1C). Significant effects of training $\left[F_{(3,183)}=30.28\right.$ $p<0.0001]$ and genotype $\left[F_{(2,183)}=3.35\right.$, $p<0.05]$ were observed for the distances swam to escape the pool during cue discrimination training (Fig. 5A). Post hoc tests of genotype effects on swim distance collapsed across training blocks, and treatment groups indicated that the distances swum by $\mathrm{ER} \alpha \mathrm{KO}$ and WT mice were less than those swum by ER $\beta$ KO mice. Separate ANOVAs within each treatment group indicated a tendency $(p=0.055)$ for genotype differences between oil-treated mice, and post hoc tests on distance collapsed across training blocks indicated that the swim distances for $\mathrm{ER} \alpha \mathrm{KO}$-oil mice were less than those for ER $\beta$ KO-oil mice (Fig. 5B). Together, these results indicate that, in the absence of estradiol treatment, middle-age ER $\alpha \mathrm{KO}$ mice exhibit better cue discrimination learning than ER $\beta K O$ mice.

Spatial discrimination training was initiated on week 6 after surgery, $48 \mathrm{~h}$ after the sixth series of cyclic injections of either estradiol or oil, and was continued for 3 consecutive days (Fig. $1 C)$. An ANOVA on escape path length revealed significant training effects $\left[F_{(2,122)}=22.42 p<0.0001\right]$ and genotype effects $\left[F_{(2,122)}=3.47, p<0.05\right]$ (Fig. $5 C$ ). Post hoc tests of the genotype effects on escape path length collapsed across days and treatment groups indicated that the escape path lengths of ER $\beta \mathrm{KO}$ mice were shorter than those for $\mathrm{ER} \alpha \mathrm{KO}$ and WT mice $(p<0.05)$. ANOVAs within each treatment group revealed that there was an effect of genotype in oil-treated mice $\left[F_{(2,62)}=3.9, p<0.05\right]$, and post hoc tests of these mice indicated that the escape path lengths for $\mathrm{ER} \beta \mathrm{KO}$ mice were less than those for $\mathrm{ER} \alpha \mathrm{KO}$ and WT mice (Fig. $5 D$ ). Thus, the effects of genotype on spatial discrimination learning appear to be opposite to those observed for cue discrimination learning; in the absence of estradiol treatment, middleage ER $\beta K O$ mice exhibit better spatial discrimination learning than $\mathrm{ER} \alpha \mathrm{KO}$ and WT mice, a difference that disappeared after estradiol treatment.

The ability of estradiol treatment to restore spatial discrimination learning in $\mathrm{ER} \alpha \mathrm{KO}$ and WT mice to ER $\beta \mathrm{KO}$ performance levels was confirmed by the probe trial data. Repeated-measures ANOVAs on the discrimination index measures for probe trials delivered as the penultimate trial on days 2 and 3 (Fig. 6A) indicated a training by treatment interaction $\left[F_{(1,61)}=5.26, p<0.05\right]$ 
and a trend for an interaction of training and genotype $(p=$ 0.08). Follow-up ANOVAs for each treatment group indicated training effects for estradiol-treated mice $\left[F_{(1,30)}=9.84, p<\right.$ 0.005], and an ANOVA for each day indicated a treatment effect on day 3 for the discrimination index $(p<0.05)$ that reflected improved performance of mice treated with estradiol. Examination of training effects for each genotype indicated that only $\mathrm{ER} \beta \mathrm{KO}$ mice showed an improvement in performance $\left[F_{(1,22)}=\right.$ 5.37, $p<0.05]$. Post hoc comparisons indicated that the performance of ER $\beta \mathrm{KO}$ mice on day 3 was significantly better than the performance of the WT ( $p<0.05$; Fig. 6A). Finally, one-tailed $t$ tests comparing search behavior to chance indicated that all estradiol-treated groups exhibited a search pattern focused on the goal quadrant on day $3(p<0.05)$. For oil-treated mice, only $\mathrm{ER} \beta \mathrm{KO}$-oil mice exhibited performances different from chance (Fig. 6A). A repeated-measures ANOVA on the number of platform crossings for days 2 and 3 indicated an effect of training $\left[F_{(1,61)}=7.16, p<0.01\right]$ and a trend $(p=$ 0.09 ) for a genotype effect. Examination of training effects in each genotype indicated that only ER $\beta \mathrm{KO}$ mice improved performance $\left[F_{(1,22)}=4.81, p<0.05\right]$. Post hoc comparisons of genotype differences for each day indicated that $\mathrm{ER} \beta \mathrm{KO}$ mice made more crossings than WT mice $(p<0.05)$ on day 3 (Fig. $6 B$ ). Thus, all groups treated with estradiol appeared to have acquired a spatial search strategy by the third day of training, and the performances of ER $\beta \mathrm{KO}$-oil mice were superior to those of the other groups treated with oil (Fig. 6B).

For gene profiling, middle-age mice (4-6 mice per group) were examined $24 \mathrm{~h}$ after the eighth series of estradiol or oil injections (Fig. 1C) using Affymetrix GeneChip Mouse Gene 1.0 ST Arrays, one array per mouse. First, we identified differentially expressed genes $(p<0.025)$ between oil and estradiol-treated mice within each genotype (Fig. 7A). A total of 2089 probes were found to be differentially expressed between WT-EB and WT-

oil-treated mice, the majority of which $(1324,63 \%)$ exhibited reduced expression. The expression level of one probe was reduced by $>2$-fold, and the expression of 2 probes increased $>2$ fold. The number of probes exhibiting differential expression in $\mathrm{ER} \alpha \mathrm{KO}-\mathrm{EB}$ mice compared with $\mathrm{ER} \alpha \mathrm{KO}$-oil mice was 916, $\sim$ half the number observed for WT mice. Although the majority of probes for $\mathrm{ER} \alpha \mathrm{KO}-\mathrm{EB}$ mice exhibited reduced expression $(509,56 \%)$, no probe was observed whose expression decreased $>2$-fold. In contrast, 31 probes exhibited a $>2$-fold increase in expression. Interestingly, the basal expression levels of these 31 probes in $\mathrm{ER} \alpha \mathrm{KO}$-oil mice were lower than observed in WT-oil mice (Fig. 7B). These highly responsive probes have been associated with the cells of the blood-brain barrier and choroid plexus (Lein et al., 2007) (Table 1). Thus, our analyses of middle-age $\mathrm{ER} \alpha \mathrm{KO}$ mice under low estradiol conditions suggest that there is a large shift in the expression of select genes associated with the blood-brain barrier and that their expression is restored to normal levels by estradiol treatment. Finally, the changes in gene expression for $\mathrm{ER} \beta \mathrm{KO}-\mathrm{EB}$ relative to $\mathrm{ER} \beta \mathrm{KO}$-oil mice were in-

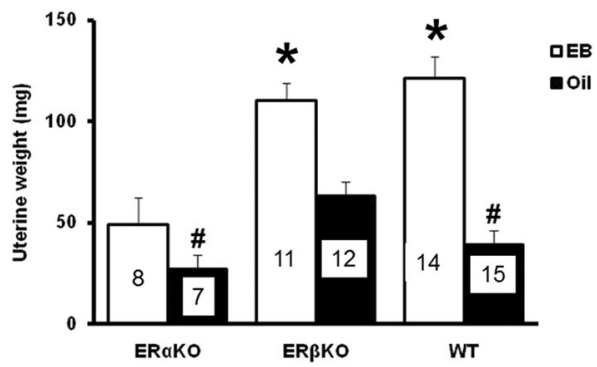

Figure 4. Uterine weight was increased by estradiol treatment (open bars) relative to oil treatment (filled bars) in ER $\beta K O$ and WT mice. The numbers in each bar indicate the number of animals in each group. *Significant $(p<0.05)$ differences between estradiol and oil treatment. \#Significant difference between oil-treated WT and ER $\alpha \mathrm{KO}$ animals relative to ER $\beta K 0$ oiltreated mice.

Figure 5. Water maze performance of middle-age ERKO and WT mice treated with estradiol (WT $=14, E R \alpha K O=8, E R \beta K O=$ bars). $\boldsymbol{B}$, Mean path length ( \pm SEM) across all cue discrimination training blocks grouped by treatment. $\boldsymbol{C}$, Mean path length to escape platform during spatial training. Spatial discrimination training was initiated on week 6 after surgery, $48 \mathrm{~h}$ after the previous injection of either estradiol or oil, and was continued for 3 consecutive days. $D$, Mean path length ( \pm SEM) across all days of spatial training grouped by treatment. "Significant differences from the ER $\beta K 0$-oil group.

termediate between WT and $\mathrm{ER} \alpha \mathrm{KO}$ mice, with 1681 probes showing differential expression. In this case, 938 probes (56\%) increased expression, and the increase for only one probe was $>2$-fold.

Next, we examined the differences in basal and estradiolinduced gene expression in $\mathrm{ER} \alpha \mathrm{KO}$ and $\mathrm{ER} \beta \mathrm{KO}$ mice relative to WT-oil-treated mice (Fig. 8). ER $\alpha \mathrm{KO}$ exhibited little change in the number of differentially expressed genes after either oil or estradiol treatments. ER $\beta \mathrm{KO}$-oil mice exhibited approximately twice as many differentially expressed probes as ER $\alpha \mathrm{KO}$-oil mice; estradiol treatment induced a fourfold increase in the number of differentially expressed genes in ER $\beta \mathrm{KO}$ mice compared with ER $\alpha \mathrm{KO}$ mice (Fig. $8 B$ ). Five or fewer probes exhibited a fold change $>2$ within each group. $\mathrm{ER} \alpha \mathrm{KO}$ and $\mathrm{ER} \beta \mathrm{KO}$ mice do not express the full-length transcripts for $\operatorname{ER} \alpha$ and $\operatorname{ER} \beta$, respectively, because of a neomycin cassette insert that functionally knocks out the gene. Therefore, it was notable that there was a threefold increase in the level of the transcript encoding the nonfunctional $\mathrm{ER} \beta$ (ESR2, gene ID 10401035) in ER $\beta \mathrm{KO}$ mice treated with 

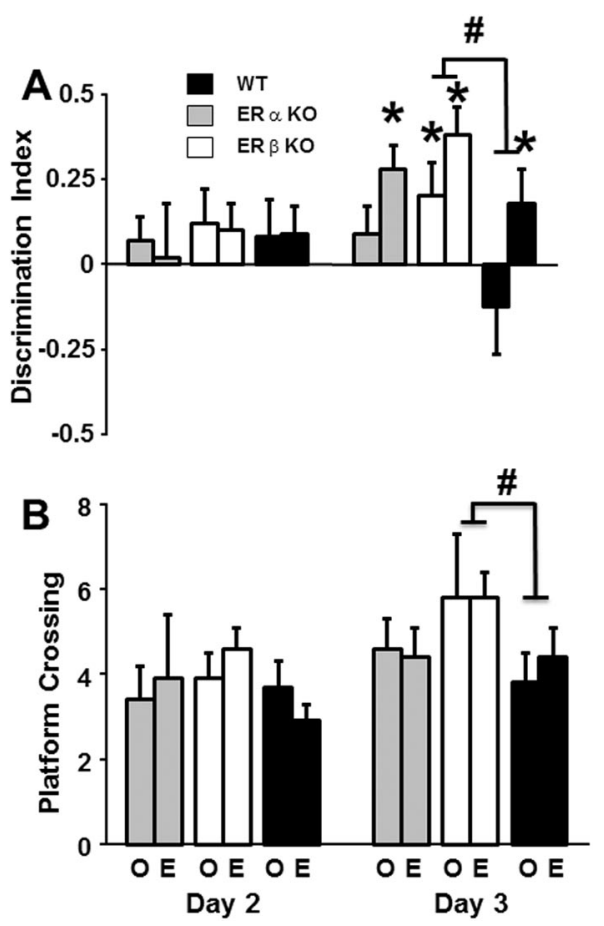

Figure 6. Probe trial measures for middle-age WT (filled bars), ER $\alpha$ KO (gray bars), and ER $\beta K O$ (open bars) mice treated with oil (0:WT $=15, \mathrm{ER} \alpha \mathrm{KO}=7$, ER $\beta K 0=12$ ) or estradiol (E:WT $=14$, $E R \alpha K O=8, E R \beta K O=11) . A$, Mean $( \pm$ SEM $)$ discrimination index calculated from probe trial performance. Probe trials were delivered as the penultimate trial on days 2 and 3 for each session. *Performance above chance and acquisition of a spatial search strategy. $\boldsymbol{B}$, Mean ( \pm SEM) platform crossing calculated from probe trial performance. "Significant genotype difference between ER $\beta K O$ and WT mice.

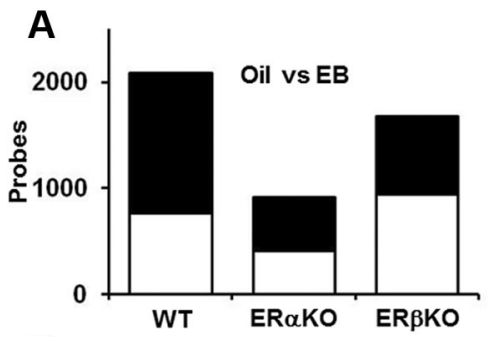

B

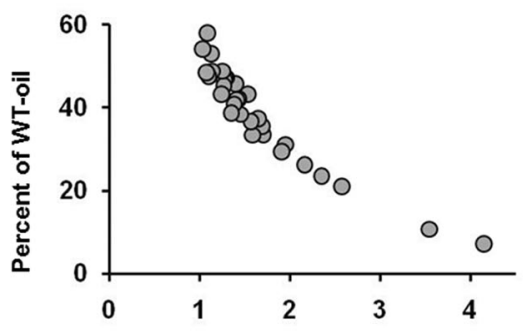

Log2 fold change for ERaKO (Oil vs EB)

Figure 7. Gene expression in middle-age WT and ERKO mice, $24 \mathrm{~h}$ after the last estradiol $(W T=14, \operatorname{ER} \alpha K 0=8, \operatorname{ER} \beta K 0=11)$ or oil $(W T=15, \operatorname{ER} \alpha K 0=7, \operatorname{ER} \beta K 0=12)$ treatment. $A$, Graphic summary of the total number of probes that increased (open) and decreased (filled) in WT-EB, ER $\alpha K 0-E B$, and ER $\beta K 0$-EB-treated mice compared with genotype-matched oiltreated counterparts. WT and ER $\beta K O$ mice exhibited $\sim 2$ times more genes whose expression was altered by estradiol relative to ER $\alpha \mathrm{KO}$ mice. $\boldsymbol{B}$, Expression of 31 probes in ER $\alpha \mathrm{KO}$ mice normalized to expression in WT-oil mice. Basal expression for ER $\alpha K 0$-oil mice is plotted on the $y$-axis, and the increase in expression observed in ER $\alpha \mathrm{KO} 0$-EB mice is plotted on the $x$-axis as the $\log 2$ fold change. either oil or estradiol, and a 2.5-fold or a twofold increase in the levels of the transcript encoding the nonfunctional ER $\alpha$ (ESR1, gene ID 10367600) in ER $\alpha \mathrm{KO}$ treated with estradiol or oil, respectively. The twofold increase in ESR1 in ER $\alpha \mathrm{KO}$-oil mice did not reach our significance cutoff $(p=0.045)$. The increased transcription of the nonfunctional ESR1 and ESR2 genes in young and middle-age ERKO mice suggests that loss of the functional receptors induces a compensatory transcription increase in these genes.

Next, we set out to determine whether the genes that were differentially expressed in $\mathrm{KO}$ mice, relative to WT-oil mice, were estradiol-sensitive genes. Estradiol-sensitive genes were defined as the set of 2089 probes that were differentially expressed between WT-oil and WT-EB mice. We used this set of genes as a "seed" to determine whether KO animals expressed an estradiolsensitive transcription profile similar to that observed in WT-EB mice. For the ER $\alpha \mathrm{KO}$-oil, ER $\alpha \mathrm{KO}-\mathrm{EB}, \mathrm{ER} \beta \mathrm{KO}$-oil, and $\mathrm{ER} \beta \mathrm{KO}$-EB groups, we determined the number of estradiolsensitive genes whose change in expression was similar to that observed in the WT-EB group. Of the probes identified, the expression levels of very few were altered in a direction opposite to that observed in WT-EB mice $(\mathrm{ER} \alpha \mathrm{KO}$-oil $=3, \mathrm{ER} \alpha \mathrm{KO}-\mathrm{EB}=4$, $\mathrm{ER} \beta \mathrm{KO}$-oil $=0, \mathrm{ER} \beta \mathrm{KO}-\mathrm{EB}=5)$. Figure $8 B$ illustrates the differential expression patterns for probes that were significantly different from WT-oil and exhibited expression changes similar to those observed in WT-EB mice. In general, twice as many estradiol-responsive genes exhibited expression changes in $\mathrm{KO}$ mice treated with estradiol than in genotype-matched mice treated with oil, an observation that suggests that knockout of either $\mathrm{ER} \alpha$ or ER $\beta$ does not completely block estradiol sensitivity in these mice. Furthermore, there were approximately four times more differentially expressed estradiol-responsive genes in $\mathrm{ER} \beta \mathrm{KO}$ mice treated with either estradiol or oil compared with $\mathrm{ER} \alpha \mathrm{KO}$ mice $(\mathrm{ER} \alpha \mathrm{KO}$ : oil $=51$, estradiol = 98; $\mathrm{ER} \beta \mathrm{KO}$ : oil $=$ 181 , estradiol $=355)$. This result further supports the idea that one role of $\mathrm{ER} \beta$ is to suppress $\mathrm{ER} \alpha$ driven gene transcription.

\section{RT-PCR}

Genes whose expression was altered in WT-EB, ER $\alpha$ KO-EB, and $\mathrm{ER} \beta \mathrm{KO}$-oil mice relative to WT-oil mice were analyzed using RT-PCR. Three mice were analyzed per group. Two genes were examined that had exhibited relatively robust 1.5 - to 2.0 -fold changes in middle-age WT-EB, ER $\alpha \mathrm{KO}-\mathrm{EB}$, and $\mathrm{ER} \beta \mathrm{KO}$-oil mice. BTG2 is an antiproliferative protein whose expression is regulated by $\operatorname{ER} \alpha$ and $\operatorname{ER} \beta$ (Karmakar et al., 2009; Paruthiyil et al., 2010), and NPAS4 is a transcription factor that influences the development of inhibitory synapses (Lin et al., 2008). The expression of these two genes decreased in ER $\beta \mathrm{KO}$-oil, $\mathrm{ER} \alpha \mathrm{KO}-\mathrm{EB}$, and WT-EB mice compared with WT-oil mice (Fig. 9A). Pearson correlation for RT-PCR and microarray values for BTG2 and NPAS4 across the groups indicated a significant relationship $(r=$ $0.83, p<0.01)$.

The arrays also suggested that there was an increase in transcription of the functionally disrupted ERs in the ER $\beta \mathrm{KO}$ and $\mathrm{ER} \alpha \mathrm{KO}$ mice, the magnitudes of which may have been underestimated because the probes flanked the neomycin inserts that were used to disrupt function of the receptors. RT-PCR confirmed that the level of transcription of functionally disrupted ESR1 was increased in $\mathrm{ER} \alpha \mathrm{KO}$ mice compared with WT-oil mice. Gene arrays revealed a sixfold increase in ESR1 transcription in young ER $\alpha \mathrm{KO}$ mice relative to WT-oil, whereas RT-PCR analyses suggested that the increase was 30 -fold higher than WToil (Fig. 10A). The increases in ESR1 transcript levels were two- 
Table 1. Genes increased > 2-fold by estradiol treatment in middle-aged ER $\alpha K 0$ mice

\begin{tabular}{|c|c|c|c|}
\hline Affymetrix probe gene ID & Protein & Symbol & Fold \\
\hline 10356403 & Potassium inwardly rectifying channel, subfamily J, member 13 & Kcnj13 & 17.67 \\
\hline 10454192 & Transthyretin & TTR & 11.63 \\
\hline 10436958 & Chloride intracellular channel 6 & Clic6 & 5.954 \\
\hline 10539393 & Solute carrier family 4, sodium bicarbonate cotransporter, member 5 & SLC4A5 & 5.09 \\
\hline 10419356 & Orthodenticle homolog 2 (Drosophila) & $0 \mathrm{tx} 2$ & 4.47 \\
\hline 10351224 & Coagulation factor V; similar to murine coagulation factor $\mathrm{V}$ & LOC100048143 & 3.86 \\
\hline 10395389 & Sclerostin domain containing 1 & SOSTDC1 & 3.74 \\
\hline 10547191 & Transmembrane protein 72 & TMEM72 & 3.26 \\
\hline 10566034 & Folate receptor 1 (adult) & FoLR1 & 3.22 \\
\hline 10602033 & Claudin 2 & CLDN2 & 3.12 \\
\hline 10599422 & RIKEN CDNA 1110059M19 gene & 1110059M19Rik & 2.99 \\
\hline 10577444 & Defensin $\beta 11$ & Defb11 & 2.97 \\
\hline 10402195 & Tandem $C 2$ domains, nuclear & $\mathrm{tc} 2 \mathrm{n}$ & 2.89 \\
\hline 10451818 & sulfotransferase family, cytosolic, 1C, member 2 & Sult1c2 & 2.74 \\
\hline 10478048 & Lipopolysaccharide binding protein & $\mathrm{lbp}$ & 2.69 \\
\hline 10586118 & Calmodulin-like 4 & calml4 & 2.65 \\
\hline 10527870 & Klotho & $\mathrm{KL}$ & 2.63 \\
\hline 10543921 & Solute carrier family 13 (sodium/sulfate symporters), member 4 & Slc13a4 & 2.60 \\
\hline 10569008 & Cytochrome c oxidase, subunit VIllb & COX8B & 2.55 \\
\hline 10495712 & ATP-binding cassette, subfamily A (ABC1), member 4 & abca4 & 2.44 \\
\hline 10428619 & Ectonucleotide pyrophosphatase/phosphodiesterase 2 & ENPP2 & 2.43 \\
\hline 10381962 & Angiotensin I converting enzyme (peptidyl-dipeptidase A) 1 & ACE & 2.41 \\
\hline 10362104 & Solute carrier family 2 (facilitated glucose transporter), member 12 & SLC2A12 & 2.40 \\
\hline 10344897 & Sulfatase 1 & Sulf1 & 2.37 \\
\hline 10373588 & Retinol dehydrogenase 5 & RDH5 & 2.37 \\
\hline 10517655 & Phospholipase A2, group V; similar to phospholipase A2, group V & LOC100048852 & 2.19 \\
\hline 10542993 & Paraoxonase 3 & PON3 & 2.18 \\
\hline 10440091 & Collagen, type VIII, $\alpha 1$ & COL8A1 & 2.14 \\
\hline 10436947 & Potassium voltage-gated channel, Isk-related subfamily, gene 2 & KCNE2 & 2.12 \\
\hline 10569344 & Insulin-like growth factor 2 & IGF2 & 2.10 \\
\hline 10584653 & C1q and tumor necrosis factor-related protein 5; membrane-type frizzled-related protein & C1QTNF5 & 2.05 \\
\hline
\end{tabular}

Genes in middle-age ER $\alpha$ KO-EB-treated mice that exhibited a $>2$-fold increase in expression relative to ER $\alpha$ KO-oil mice.
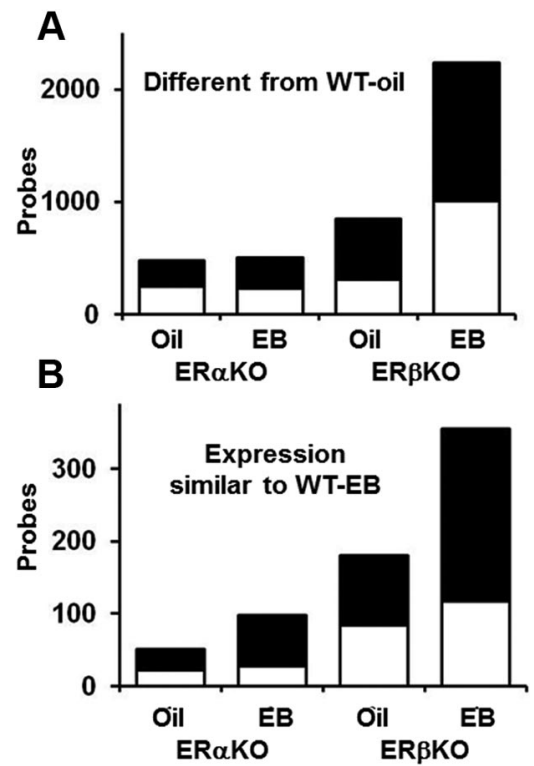

Figure 8. Illustration of the total number of probes showing significant increases (open) and decreases (filled) in ER $\alpha K O$ or ER $\beta K O$ oil (ER $\alpha K O=7$, ER $\beta K O=12$ ) and estradiol-treated $(E R \alpha K O=8$, ER $\beta K O=11)$ mice compared with WT-oil mice $(n=15)$. $A$, Compared with ER $\alpha K O$ mice, ER $\beta K O$ mice exhibited more genes that were altered under oil conditions. Treatment with estradiol resulted in a further increase in the number of altered genes in ER $\beta K O$ mice with little evidence of an estradiol effect on gene expression in ER $\alpha$ KO mice. $B$, Analysis was limited to a subset of genes that showed altered expression in WT-EB compared with WT-oil mice (i.e., estradiolresponsive genes). The number of estradiol-responsive genes is plotted for $\mathrm{KO}$ mice. Four times more genes in ER $\beta K O$ mice than in ER $\alpha K O$ mice exhibited changes that matched those observed in WT-EB under oil and estradiol treatment conditions.

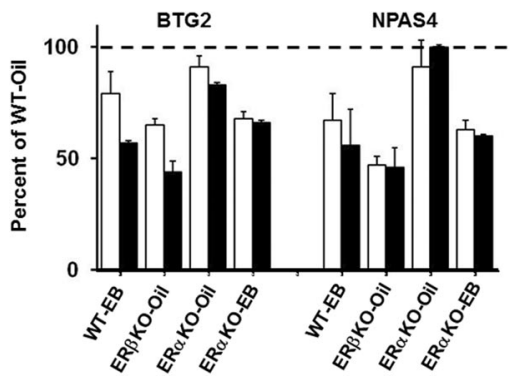

Figure 9. RT-PCR confirmation of the expression patterns observed for a subset of genes. Comparisons of the expression levels of two genes, BTG2 and NPAS4, determined by microarray (open bars) for mice treated with oil (ER $\alpha$ KO-oil: $n=7$, ER $\beta K 0$-oil: $n=12$ ) or estradiol (WT-EB: $n=14$, ER $\alpha K 0$-EB: $n=8$, ER $\beta K 0$-EB: $n=11$ ) and RT-PCR (filled bars, $n=3$ for each condition), illustrating that expression was decreased by estradiol treatment in WT, ER $\alpha K 0$, and ER $\beta K 0$-oil mice. Expression is presented as percentage of WT-oil for microarray $n=15$ and RT-PCR $n=3$.

fold and eightfold higher for middle-age ER $\alpha \mathrm{KO}$ mice using gene arrays or RT-PCR, respectively (Fig. 10B). Similarly, ESR2 transcript levels were higher in $\mathrm{ER} \beta \mathrm{KO}$ mice (Fig. $10 C, D$ ) relative to WT-oil, and the observed increases determined using RT-PCR were greater than those obtained from the gene arrays.

\section{Viral expression of ER $\beta$ impairs spatial learning in ER $\beta$ KO mice}

Our experimental data indicate that, in the absence of estradiol treatment, middle-age ER $\beta \mathrm{KO}$ mice exhibit better spatial discrimination learning than $\mathrm{ER} \alpha \mathrm{KO}$ and WT mice. To further investigate this observation, we ovariectomized and bilaterally 
A

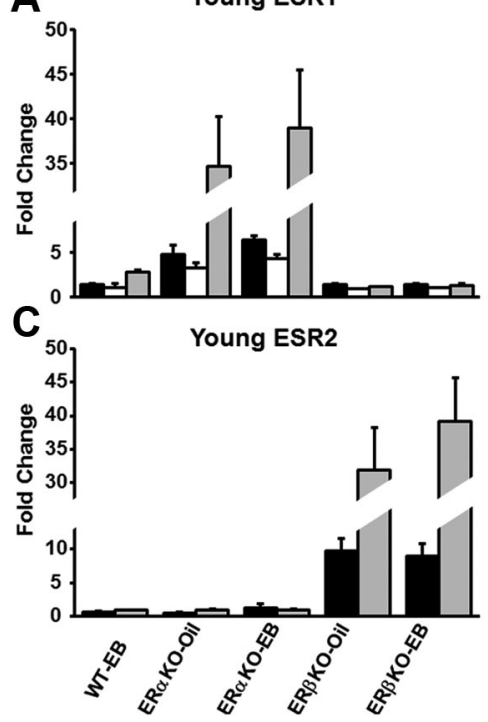

B
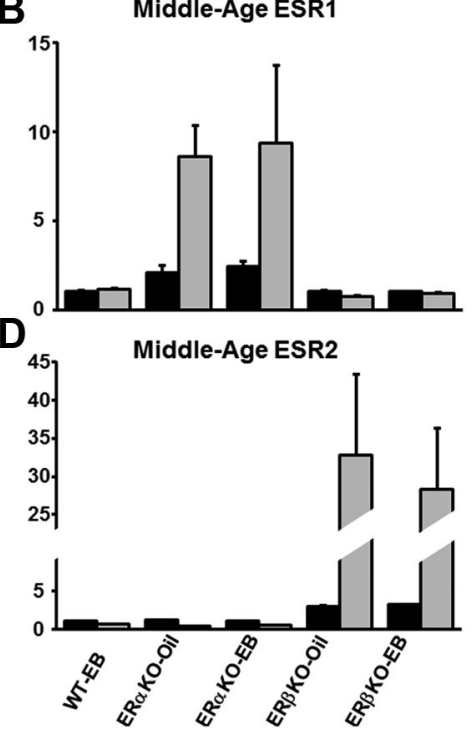

Figure 10. RT-PCR confirmation of the expression pattern for ESR1 and ESR2 in ER $\alpha K 0$ and ER $\beta K 0$ mice. $\boldsymbol{A}$, The expression of ESR1 was increased in $(\boldsymbol{A})$ young and $(\boldsymbol{B})$ middle-age ER $\alpha$ KO mice. Note that the increase in ESR1 was considerably reduced in middle-age ER $\alpha$ KO mice. ESR2 expression was increased in $(\boldsymbol{C})$ young and $(\boldsymbol{D})$ middle-age ER $\beta K 0$ mice. $\boldsymbol{A}$, Data are presented for microarray probes 1435663_at (filled bars) and 1457877_at (open bars) for mice treated with oil (ER $\alpha$ KO-oil: $n=5$, ER $\beta$ K0-oil: $n=5$ ) or estradiol (WT-EB: $n=7$, ER $\alpha$ KO-EB: $n=5$, ER $\beta$ KO-EB: $n=7$ ) and RT-PCR (gray bars, $n=3$ for each condition). $\boldsymbol{B}-\boldsymbol{D}$, Data are presented for microarray (filled bars) for mice treated with oil (ER $\alpha$ KO-oil: $n=7$, ER KKO-oil: $n=12$ ) or estradiol (WT-EB: $n=14, \mathrm{ER} \alpha \mathrm{KO}-\mathrm{EB}: n=8$, ER $\beta$ KO-EB: $n=11$ ) and for RT-PCR (gray bars, $n=3$ for each condition). All values are expressed as a fold change relative to the condition matched WT-oil (young microarray $n=7$ and RT-PCR $n=3$, middle-age microarray $n=$ 15 and RT-P(R $n=3)$. Error bars represent SEM.
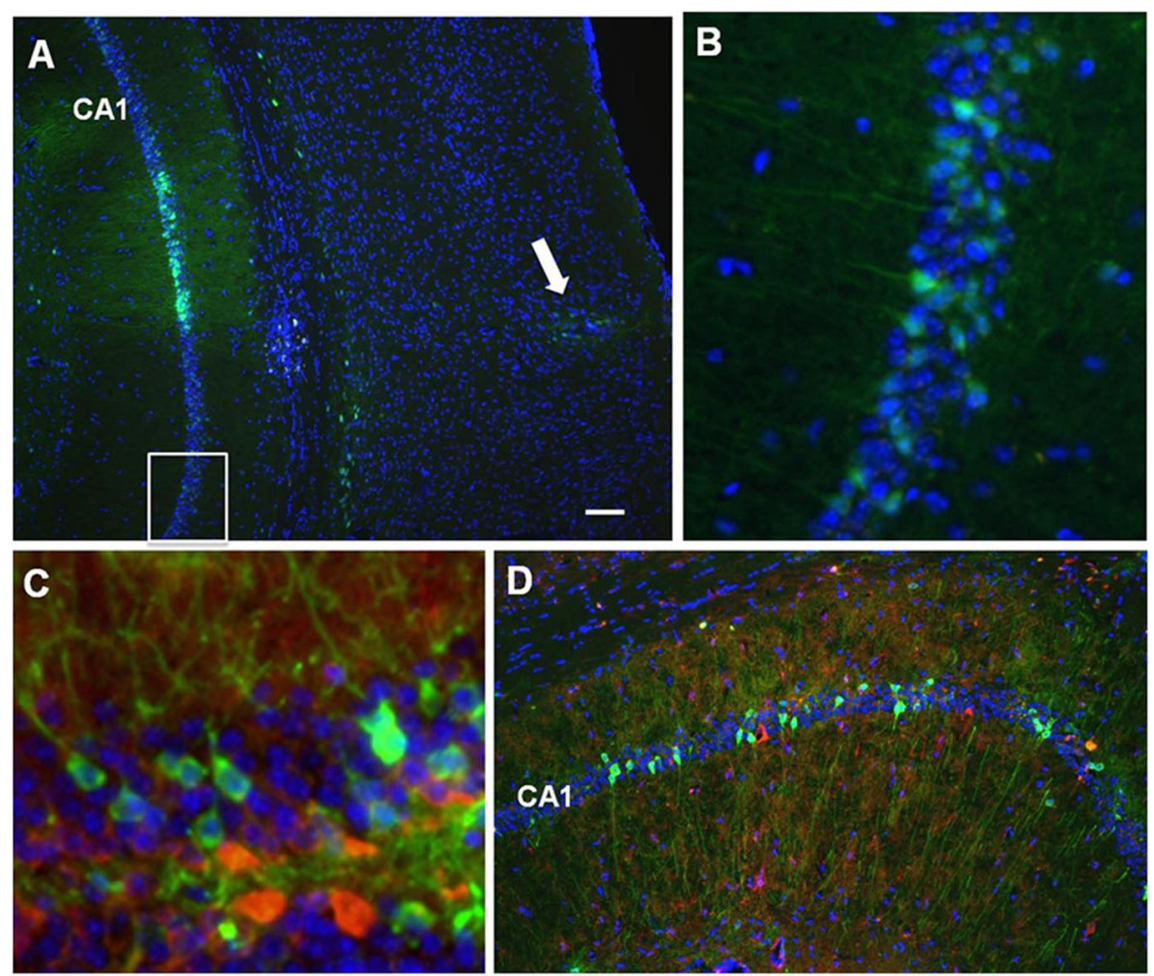

Figure 11. Lentiviral-mediated expression of $E R \beta$ and GFP in the hippocampus of ER $\beta K 0$ mice. $\boldsymbol{A}$, Expression is largely limited to the hippocampus and the needle track (arrow). Intense GFP expression (green) is observed in region CA1 near the injection site and was detectable several hundreds of microns from the injection site (box). $\boldsymbol{B}$, Enlarged view of the box shown in $\boldsymbol{A}$. C, ER $\beta$-FLAG (red) and GFP (green) in the dentate gyrus showing perinuclear expression ER $\beta$-FLAG while GFP could be observed filling dendrites. $\boldsymbol{D}$, Expression of GFP (green) and ER $\beta$-FLAG (red) in region CA1. Scale bar: $\boldsymbol{A}$, $50 \mu \mathrm{m}$.

injected the hippocampi of middle-age (13-14 months) ER $\beta K O$ mice with lentivirus encoding both ER $\beta$-FLAG and GFP $(n=12)$ or GFP alone $(n=11)$ to determine whether expression of $\operatorname{ER} \beta$ in the hippocampus of these mice disrupted spatial learning. Training on the cue discrimination task was performed 5 weeks after surgery. Expression of FLAG-tagged ER $\beta$ was detected using an anti-FLAG antibody. Consistent with our previous study in which we examined lentiviralmediated expression of $\mathrm{ER} \alpha$ in the hippocampus (Foster et al., 2008), histological examination of the injected hippocampi indicated that the expression of ER $\beta$-FLAG and GFP was primarily localized to the hippocampus with limited expression in the cortex along the needle track (Fig. 11A). Intense expression of the viral transgenes was observed near the site of injection; however, considerable expression was observed several hundred microns on either side of the injection site (Fig. 11B). ER $\beta$-FLAG was largely extranuclear in the cell bodies of pyramidal and granule cells with diffuse expression in the apical dendritic regions (Fig. 11C, $D$ ). In contrast, GFP could be observed filling the soma and dendritic processes (Fig. 11C).

Analyses of the behaviors of these mice showed that there was a significant effect of training $\left[F_{(3,63)}=15.46, p<0.0001\right]$ for distance to escape the pool during cue discrimination training in the absence of an effect of viral injection (Fig. 12A). Spatial discrimination training was initiated 6 weeks after surgery. An ANOVA on escape path length indicated a significant effect of training block $\left[F_{(2,42)}=27.28, p<0.0001\right]$ and a tendency $(p=0.06)$ for an effect of virus injection (Fig. 12B). Post hoc tests for each day indicated that ER $\beta \mathrm{KO}$ mice injected with virus encoding GFP (ER $\beta$ KOGFP) exhibited a significantly shorter path length on day 2 than $E R \beta K O$ mice injected with virus encoding ER $\beta$-FLAG. Examination of the probe trial discrimination index scores indicated a tendency $(p=0.07)$ for a training effect. The discrimination scores for ER $\beta$ KO-GFP mice increased across days $\left[F_{(1,10)}=7.35, p<0.05\right]$, and a tendency for a treatment effect $(p=0.055)$ was observed for day 3 with ER $\beta$ KO-GFP mice showing increased learning (Fig. 12C). A repeatedmeasures ANOVA for platform crossings revealed a treatment effect $\left[F_{(1,21)}=\right.$ $4.88, p<0.05]$ that reflected an higher number of platform crossings by ER $\beta K O-G F P$ mice compared with ER $\beta$ FLAG-expressing mice (Fig. 12D). Together, these results indicate that 
expression of ER $\beta$ in the hippocampus impaired cognition under conditions of low estradiol, and suggest that hippocampal ER $\beta$ expression plays a role in cognition in adults.

\section{Discussion}

\section{Expression of ER $\alpha$ and ER $\beta$ influences} spatial learning

The current study indicates that cognitive function is affected by interactions between $\mathrm{ER} \alpha$ and $\mathrm{ER} \beta$ and estradiol exposure history. The learning performances of young (Fig. 3) and middle-age ovariectomized ER $\beta$ KO-oil mice (Figs. 5 and 6) were superior to those observed for WT-oil and $\mathrm{ER} \alpha \mathrm{KO}$-oil mice, indicating that removal of ER $\beta$ preserved learning abilities in these hormone-deprived mice. Importantly, we found that expression of $E R \beta$ in the hippocampi of ovariectomized, middle-age $\mathrm{ER} \beta \mathrm{KO}$ mice reversed the benefits of functional knockout of ER $\beta$.

Daily injections of estradiol benzoate (1-5 $\mu \mathrm{g})$ improve spatial memory in mice (Frick et al., 2002; Li et al., 2004; Xu and Zhang, 2006); however, higher doses can impair learning (Fugger et al., 1998). We confirmed that estradiol injections $(5 \mu \mathrm{g})$ can have lasting ( $48-72 \mathrm{~h}$ ) effects on cognition (Aenlle et al., 2009). In addition, estradiol treatment induced lasting memory enhancement in middle-age $\mathrm{ER} \alpha \mathrm{KO}$ mice, a finding that extends previous work showing that estradiol improves cognition in young ER $\alpha \mathrm{KO}$ mice (Fugger et al., 2000; Liu et al., 2008). Improved learning in $\mathrm{ER} \alpha \mathrm{KO}-\mathrm{EB}$ mice was observed $72 \mathrm{~h}$ after the last treatment, suggesting likely genomic rather than membrane effects. Injection of $5 \mu \mathrm{g}$ estradiol is expected to produce a supraphysiological rise in serum estradiol, which then declines to basal levels by $72 \mathrm{~h}$ after the last injection (Gordon et al., 1986; Woolley and McEwen, 1993; Noppens et al., 2005). Finally, our observations extend previous reports that estradiol treatment does not facilitate memory in young ER $\beta$ KO mice (Fugger et al., 2000; Liu et al., 2008; Walf et al., 2009) to middle-age ER $\beta \mathrm{KO}$ mice.

\section{ER $\alpha \mathrm{KO}$ mice: estradiol treatment required for compensation} of a loss of ER $\alpha$

Young ER $\alpha \mathrm{KO}$ and WT mice exhibited a similar pattern in gene expression $6 \mathrm{~h}$ after estradiol treatment (Fig. 2), suggesting that there are compensatory mechanisms that regulate gene transcription in response to estradiol in the absence of $\mathrm{ER} \alpha$. Furthermore, estradiol facilitated memory $72 \mathrm{~h}$ after treatment in middle-age $\mathrm{ER} \alpha \mathrm{KO}$ mice, suggesting that these compensatory mechanisms contribute to estradiol effects on memory. However, the ability of $\mathrm{ER} \alpha \mathrm{KO}$ mice to respond to estradiol may diminish as a function of age because the similarities between the ER $\alpha \mathrm{KO}-\mathrm{EB}$ and WT-EB transcriptomes were reduced in middle-age $\mathrm{ER} \alpha \mathrm{KO}-\mathrm{EB}$ mice (Fig. $8 A$ ).

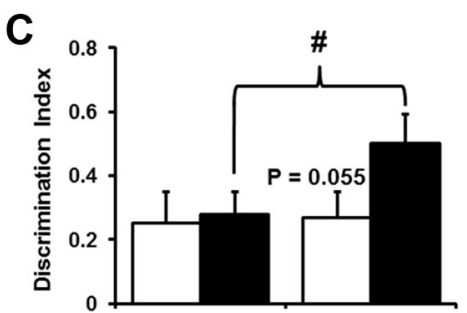

D

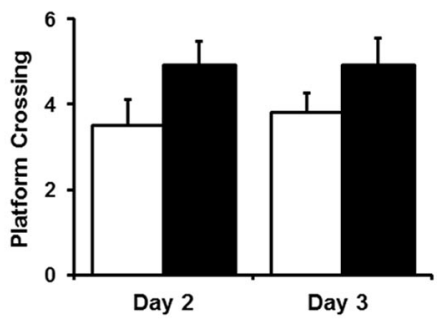

Figure 12. Hippocampal expression of $E R \beta$ in middle-age ER $\beta K O$ mice impairs water maze spatial learning. $\boldsymbol{A}$, Mean path length to reach an escape platform over four training blocks for ER $\beta$ KO mice expressing GFP (filled circles and bars, $n=11$ ) or GFP and ER $\beta$-FLAG (open circles and bars, $n=12$ ). A decrease in path length was observed in the absence of a treatment effect. $\boldsymbol{B}$ 列 increase in the discrimination index score across the $2 \mathrm{~d}$ of training. A tendency $(p=0.055)$ for a treatment effect was observed for day 3, with increased learning for ER $\beta$ KO-GFP mice. $D$, Platform crossing calculated from probe trial performance. ER $\beta$ KO-GFP Balance of estradiol and ER expression during aging

Figure 13. Hippocampal estradiol-sensitive gene expression and memory function depend on the relative level of expression of $\operatorname{ER} \alpha$ and $\operatorname{ER} \beta$. $A$, A decrease in estradiol and reduced expression of $E R \alpha$ relative to $E R \beta$ during menopause disrupts the transcriptional processes that normally help preserve cognitive function. $\boldsymbol{B}$, Increasing the expression of ER $\alpha$ relative to ER $\beta$ preserves transcription and memory, even as estradiol levels decline.

Middle-age ER $\alpha \mathrm{KO}$-oil mice exhibited reduced expression of genes expressed in capillaries and the choroid plexus, including genes involved in blood-brain barrier transport, several of which (TTR, CLIC6, and KCNJ13) are sensitive to aging in the human hippocampus (Kang et al., 2011). Several of these genes have also been linked to neurodegenerative diseases, including the deposition of amyloid $\beta$ (Hong-Goka and Chang, 2004; Tang et al., 2004; Quintela et al., 2009) and tau regulation (Woo et al., 2010). These results suggest that blood-brain barrier transport processes may be disrupted by aging and exacerbated by extended loss of $\mathrm{ER} \alpha$ activity; nevertheless, our results indicate that $\mathrm{ER} \alpha$ independent and estradiol-sensitive mechanisms exist that can sustain these processes in the presence of hormone replacement.

\section{ER $\beta$ KO mice: ER $\beta$ regulation of transcription and} hippocampal function

Superior spatial learning was observed in middle-age ER $\beta K O$ mice, an advantage that was negated by hippocampal expression of $\mathrm{ER} \beta$. This result suggests that knockout of $\mathrm{ER} \beta$ provided pro- 
tection against cognitive decline. Furthermore, ER $\beta$ KO mice exhibited a marked shift in basal transcription of estradiolresponsive genes (Figs. 2 and 8), suggesting that the shift in transcription may have contributed to preserved cognition in ER $\beta K O$ mice. A similar finding has been reported in bone, such that aging ER $\beta \mathrm{KO}$ mice are protected from bone loss (Windahl et al., 2001) and show increased transcription of estradiol-responsive genes (Lindberg et al., 2003). Furthermore, knockdown of ER $\beta$ has been shown to reduce the vulnerability of hippocampal cells to oxidative stress (Yang et al., 2009).

The increased basal transcription of estradiol-responsive genes in the hippocampi of ER $\beta \mathrm{KO}$-oil mice is likely the result of several factors. Cell culture studies indicate that ER $\beta$ antagonizes ER $\alpha$-mediated transcription (Hall and McDonnell, 1999; Pettersson et al., 2000; Gottfried-Blackmore et al., 2007). Similarly, ER $\alpha$-associated transcriptional activity in bone (Lindberg et al., 2003) and aortic tissue (O'Lone et al., 2007) is enhanced in $\mathrm{ER} \beta \mathrm{KO}$ mice. In brain regions that express both receptors, estradiolinduced transcription declines as the levels of $\operatorname{ER} \alpha$ and $\operatorname{ER} \beta$ shift to favor ER $\beta$ (Gonzales et al., 2008). A second factor that influences basal transcription is the affinity of estradiol for $\operatorname{ER} \alpha$ and $\operatorname{ER} \beta$. Low levels of estradiol are synthesized in the hippocampus (Prange-Kiel et al., 2003; Kretz et al., 2004) and low concentrations of estradiol favor activation of ER $\alpha$ (Kuiper et al., 1997; Tremblay et al., 1997; Barkhem et al., 1998; Pettersson et al., 2000).Together, these results suggest that transcription of estradiol-sensitive genes in $\mathrm{ER} \beta \mathrm{KO}$-oil mice reflects a release of $\mathrm{ER} \beta$ inhibition of ER $\alpha$-mediated transcription.

\section{Interaction of $\operatorname{ER} \alpha$ and $E R \beta$ signaling pathways}

The ERs knocked out in our mice were absent during fetal development. However, differences that we observed in cognition cannot be ascribed to developmental effects alone. First, superior performance of the ER $\beta \mathrm{KO}$ mice relative to the $\mathrm{ER} \alpha \mathrm{KO}$ and WT mice was limited to conditions of hormone deprivation, indicating that changes in hormone levels were required to reveal the interactions between $\mathrm{ER} \beta$ and $\mathrm{ER} \alpha$. Second, in middle-age $\mathrm{ER} \beta \mathrm{KO}$ mice, lentiviral-mediated expression of ER $\beta$ in the hippocampus impaired cognition, indicating that hippocampal ER $\beta$ expression plays a role in cognition in adults. Indeed, loss of ER $\beta$ expression in tissues other than the hippocampus may be a more significant problem for aging animals. At $\sim 2$ years of age, $\mathrm{ER} \beta \mathrm{KO}$ mice exhibit excessive weight gain and develop pituitary tumors and myeloproliferative disease, changes that suggest loss of ER $\beta$ may induce an excessive growth response (Shim et al., 2003; Fan et al., 2010). Furthermore, there is evidence that brain regions outside the hippocampus may exhibit degeneration in aged ER $\beta$ KO mice (Wang et al., 2001).

Interactions between $\mathrm{ER} \alpha$ and $\mathrm{ER} \beta$ in younger animals may provide a mechanism for the regulation of hippocampal function and gene expression in an environment of fluctuating hormone levels (Foster, 2005, 2012). In young ER $\beta \mathrm{KO}$ mice, estradiol treatment decreased expression of a number of estradiolresponsive genes, an observation that suggests that excessive ER $\alpha$ activity can produce large-scale transcriptional changes in estradiol responsive pathways. This feedback process may contribute to decreased ER $\alpha$ expression after administration of supraphysiological levels of estradiol (Iivonen et al., 2006). Previous work indicates that young ER $\beta \mathrm{KO}$ mice exhibit learning impairments and a decline in the expression of $\operatorname{ER} \alpha$ when chronically treated with estradiol (Rissman et al., 2002), changes that could reflect the absence of $\mathrm{ER} \beta$ regulation of $\mathrm{ER} \alpha$ activity (Foster, 2012). Interestingly, we observed that transcription of nonfunctional
ESR1 and ESR2 increased in ER $\alpha \mathrm{KO}$ and $\mathrm{ER} \beta \mathrm{KO}$ mice, respectively, results consistent with the idea that the activities of these receptors play a role in regulating their transcription.

\section{$\operatorname{ER} \alpha$ and $\operatorname{ER} \beta$ over the life span}

The results indicate that maintenance of hippocampal function depends on a balance between estradiol levels and the relative level of expression of $\operatorname{ER} \alpha$ and $\operatorname{ER} \beta$ (Fig. 13). Aging is associated with decreased expression of hippocampal ER $\alpha$ or the expression of dominant-negative $\mathrm{ER} \alpha$ splice variants that could reduce the ability of estradiol treatments to preserve cognition (Tohgi et al., 1995; Adams et al., 2002; Mehra et al., 2005; Ishunina et al., 2007; Bohacek and Daniel, 2009). A decrease in estradiol and reduced expression of $\mathrm{ER} \alpha$ relative to $\mathrm{ER} \beta$ during menopause would be predicted to act in concert to decrease transcriptional processes that normally help preserve cognitive function (Fig. 13A). Indeed, ER $\alpha$ polymorphisms have been associated with greater memory impairment during menopause as estradiol levels decrease (Ji et al., 2000; Corbo et al., 2006; Olsen et al., 2006; Yaffe et al., 2009). Our results indicate that increasing the expression of $\mathrm{ER} \alpha$ may preserve transcription and memory, even as estradiol levels decline (Fig. 13B). These results are consistent with mounting evidence that suggest that increased ER $\alpha$ expression is associated with improved learning and memory (Foster, 2012). Treatments to alter the expression of ERs within the hippocampus could provide an alternative to hormone replacement in preserving cognitive function.

\section{References}

Adams MM, Fink SE, Shah RA, Janssen WG, Hayashi S, Milner TA, McEwen BS, Morrison JH (2002) Estrogen and aging affect the subcellular distribution of estrogen receptor- $\alpha$ in the hippocampus of female rats. J Neurosci 22:3608-3614. Medline

Aenlle KK, Foster TC (2010) Aging alters the expression of genes for neuroprotection and synaptic function following acute estradiol treatment. Hippocampus 20:1047-1060. CrossRef Medline

Aenlle KK, Kumar A, Cui L, Jackson TC, Foster TC (2009) Estrogen effects on cognition and hippocampal transcription in middle-aged mice. Neurobiol Aging 30:932-945. CrossRef Medline

Akama KT, McEwen BS (2003) Estrogen stimulates postsynaptic density-95 rapid protein synthesis via the Akt/protein kinase B pathway. J Neurosci 23:2333-2339. Medline

Barkhem T, Carlsson B, Nilsson Y, Enmark E, Gustafsson J, Nilsson S (1998) Differential response of estrogen receptor $\alpha$ and estrogen receptor $\beta$ to partial estrogen agonists/antagonists. Mol Pharmacol 54:105-112. Medline

Bimonte-Nelson HA, Francis KR, Umphlet CD, Granholm AC (2006) Progesterone reverses the spatial memory enhancements initiated by tonic and cyclic oestrogen therapy in middle-aged ovariectomized female rats. Eur J Neurosci 24:229-242. CrossRef Medline

Blalock EM, Chen KC, Sharrow K, Herman JP, Porter NM, Foster TC, Landfield PW (2003) Gene microarrays in hippocampal aging: statistical profiling identifies novel processes correlated with cognitive impairment. J Neurosci 23:3807-3819. Medline

Bohacek J, Daniel JM (2009) The ability of oestradiol administration to regulate protein levels of oestrogen receptor $\alpha$ in the hippocampus and prefrontal cortex of middle-aged rats is altered following long-term ovarian hormone deprivation. J Neuroendocrinol 21:640-647. CrossRef Medline

Choi JM, Romeo RD, Brake WG, Bethea CL, Rosenwaks Z, McEwen BS (2003) Estradiol increases pre- and post-synaptic proteins in the CA1 region of the hippocampus in female rhesus macaques (Macaca mulatta). Endocrinology 144:4734-4738. CrossRef Medline

Corbo RM, Gambina G, Ruggeri M, Scacchi R (2006) Association of estrogen receptor $\alpha$ (ESR1) PvuII and XbaI polymorphisms with sporadic Alzheimer's disease and their effect on apolipoprotein E concentrations. Dement Geriatr Cogn Disord 22:67-72. CrossRef Medline

Daniel JM, Hulst JL, Berbling JL (2006) Estradiol replacement enhances working memory in middle-aged rats when initiated immediately after 
ovariectomy but not after a long-term period of ovarian hormone deprivation. Endocrinology 147:607-614. CrossRef Medline

Dubal DB, Rau SW, Shughrue PJ, Zhu H, Yu J, Cashion AB, Suzuki S, Gerhold LM, Bottner MB, Dubal SB, Merchanthaler I, Kindy MS, Wise PM (2006) Differential modulation of estrogen receptors (ERs) in ischemic brain injury: a role for $\mathrm{ER} \alpha$ in estradiol-mediated protection against delayed cell death. Endocrinology 147:3076-3084. CrossRef Medline

Enmark E, Gustafsson JA (1999) Oestrogen receptors: an overview. J Intern Med 246:133-138. CrossRef Medline

Fan X, Gabbi C, Kim HJ, Cheng G, Andersson LC, Warner M, Gustafsson JA (2010) Gonadotropin-positive pituitary tumors accompanied by ovarian tumors in aging female ER $\beta^{-1-}$ mice. Proc Natl Acad Sci U S A 107:6453-6458. CrossRef Medline

Foster TC (2005) Interaction of rapid signal transduction cascades and gene expression in mediating estrogen effects on memory over the life span. Front Neuroendocrinol 26:51-64. CrossRef Medline

Foster TC (2012) Role of estrogen receptor $\alpha$ and $\beta$ expression and signaling on cognitive function during aging. Hippocampus 22:656-669. CrossRef Medline

Foster TC, Sharrow KM, Kumar A, Masse J (2003) Interaction of age and chronic estradiol replacement on memory and markers of brain aging. Neurobiol Aging 24:839-852. CrossRef Medline

Foster TC, Rani A, Kumar A, Cui L, Semple-Rowland SL (2008) Viral vector-mediated delivery of estrogen receptor- $\alpha$ to the hippocampus improves spatial learning in estrogen receptor- $\alpha$ knock-out mice. Mol Ther 16:1587-1593. CrossRef Medline

Frick KM, Fernandez SM, Bulinski SC (2002) Estrogen replacement improves spatial reference memory and increases hippocampal synaptophysin in aged female mice. Neuroscience 115:547-558. CrossRef Medline

Fugger HN, Cunningham SG, Rissman EF, Foster TC (1998) Sex differences in the activational effect of $\mathrm{ER} \alpha$ on spatial learning. Horm Behav 34:163170. CrossRef Medline

Fugger HN, Foster TC, Gustafsson J, Rissman EF (2000) Novel effects of estradiol and estrogen receptor $\alpha$ and $\beta$ on cognitive function. Brain Res 883:258-264. CrossRef Medline

Garcia-Segura LM, Sanz A, Mendez P (2006) Cross-talk between IGF-I and estradiol in the brain: focus on neuroprotection. Neuroendocrinology 84:275-279. CrossRef Medline

Gibbs RB (2000) Long-term treatment with estrogen and progesterone enhances acquisition of a spatial memory task by ovariectomized aged rats. Neurobiol Aging 21:107-116. CrossRef Medline

Gonzales KL, Tetel MJ, Wagner CK (2008) Estrogen receptor (ER) $\beta$ modulates $\mathrm{ER} \alpha$ responses to estrogens in the developing rat ventromedial nucleus of the hypothalamus. Endocrinology 149:4615-4621. CrossRef Medline

Gordon MN, Osterburg HH, May PC, Finch CE (1986) Effective oral administration of $17 \beta$-estradiol to female C57BL/6J mice through the drinking water. Biol Reprod 35:1088-1095. CrossRef Medline

Gottfried-Blackmore A, Croft G, McEwen BS, Bulloch K (2007) Transcriptional activity of estrogen receptors $\mathrm{ER} \alpha$ and $\mathrm{ER} \beta$ in the EtC. 1 cerebellar granule cell line. Brain Res 1186:41-47. CrossRef Medline

Gould E, Woolley CS, Frankfurt M, McEwen BS (1990) Gonadal steroids regulate dendritic spine density in hippocampal pyramidal cells in adulthood. J Neurosci 10:1286-1291. Medline

Gresack JE, Frick KM (2006) Effects of continuous and intermittent estrogen treatments on memory in aging female mice. Brain Res 1115:135-147. CrossRef Medline

Hall JM, McDonnell DP (1999) The estrogen receptor $\beta$-isoform (ER $\beta$ ) of the human estrogen receptor modulates $\mathrm{ER} \alpha$ transcriptional activity and is a key regulator of the cellular response to estrogens and antiestrogens. Endocrinology 140:5566-5578. CrossRef Medline

Hammer RE, Idzerda RL, Brinster RL, McKnight GS (1986) Estrogen regulation of the avian transferrin gene in transgenic mice. Mol Cell Biol 6:1010-1014. CrossRef Medline

Harrington WR, Sheng S, Barnett DH, Petz LN, Katzenellenbogen JA, Katzenellenbogen BS (2003) Activities of estrogen receptor $\alpha$ - and $\beta$-selective ligands at diverse estrogen responsive gene sites mediating transactivation or transrepression. Mol Cell Endocrinol 206:13-22. CrossRef Medline

Hong-Goka BC, Chang FL (2004) Estrogen receptors $\alpha$ and $\beta$ in choroid plexus epithelial cells in Alzheimer's disease. Neurosci Lett 360:113-116. CrossRef Medline
Iivonen S, Heikkinen T, Puoliväli J, Helisalmi S, Hiltunen M, Soininen H, Tanila H (2006) Effects of estradiol on spatial learning, hippocampal cytochrome P450 19, and estrogen $\alpha$ and $\beta$ mRNA levels in ovariectomized female mice. Neuroscience 137:1143-1152. CrossRef Medline

Ishunina TA, Fischer DF, Swaab DF (2007) Estrogen receptor $\alpha$ and its splice variants in the hippocampus in aging and Alzheimer's disease. Neurobiol Aging 28:1670-1681. CrossRef Medline

Jelks KB, Wylie R, Floyd CL, McAllister AK, Wise P (2007) Estradiol targets synaptic proteins to induce glutamatergic synapse formation in cultured hippocampal neurons: critical role of estrogen receptor- $\alpha$. J Neurosci 27:6903-6913. CrossRef Medline

Ji Y, Urakami K, Wada-Isoe K, Adachi Y, Nakashima K (2000) Estrogen receptor gene polymorphisms in patients with Alzheimer's disease, vascular dementia and alcohol-associated dementia. Dement Geriatr Cogn Disord 11:119-122. CrossRef Medline

Kang HJ, Kawasawa YI, Cheng F, Zhu Y, Xu X, Li M, Sousa AM, Pletikos M, Meyer KA, Sedmak G, Guennel T, Shin Y, Johnson MB, Krsnik Z, Mayer S, Fertuzinhos S, Umlauf S, Lisgo SN, Vortmeyer A, Weinberger DR, et al. (2011) Spatio-temporal transcriptome of the human brain. Nature 478 : 483-489. CrossRef Medline

Karmakar S, Foster EA, Smith CL (2009) Estradiol downregulation of the tumor suppressor gene BTG2 requires estrogen receptor- $\alpha$ and the REA corepressor. Int J Cancer 124:1841-1851. CrossRef Medline

Katzenellenbogen BS, Korach KS (1997) A new actor in the estrogen receptor drama: enter ER- $\beta$. Endocrinology 138:861-862. CrossRef Medline

Krege JH, Hodgin JB, Couse JF, Enmark E, Warner M, Mahler JF, Sar M, Korach KS, Gustafsson JA, Smithies O (1998) Generation and reproductive phenotypes of mice lacking estrogen receptor $\beta$. Proc Natl Acad Sci U S A 95:15677-15682. CrossRef Medline

Kretz O, Fester L, Wehrenberg U, Zhou L, Brauckmann S, Zhao S, PrangeKiel J, Naumann T, Jarry H, Frotscher M, Rune GM (2004) Hippocampal synapses depend on hippocampal estrogen synthesis. J Neurosci 24: 5913-5921. CrossRef Medline

Kuiper GG, Carlsson B, Grandien K, Enmark E, Häggblad J, Nilsson S, Gustafsson JA (1997) Comparison of the ligand binding specificity and transcript tissue distribution of estrogen receptors $\alpha$ and $\beta$. Endocrinology 138:863-870. CrossRef Medline

Lee WH, Kumar A, Rani A, Herrera J, Xu J, Someya S, Foster TC (2012) Influence of viral vector-mediated delivery of superoxide dismutase and catalase to the hippocampus on spatial learning and memory during aging. Antioxid Redox Signal 16:339-350. CrossRef Medline

Lein ES, Hawrylycz MJ, Ao N, Ayres M, Bensinger A, Bernard A, Boe AF, Boguski MS, Brockway KS, Byrnes EJ, Chen L, Chen L, Chen TM, Chin MC, Chong J, Crook BE, Czaplinska A, Dang CN, Datta S, Dee NR,et al. (2007) Genome-wide atlas of gene expression in the adult mouse brain. Nature 445:168-176. CrossRef Medline

Li J, Wong L (2001) Emerging patterns and gene expression data. Genome Inform 12:3-13. Medline

Li C, Brake WG, Romeo RD, Dunlop JC, Gordon M, Buzescu R, Magarinos AM, Allen PB, Greengard P, Luine V, McEwen BS (2004) Estrogen alters hippocampal dendritic spine shape and enhances synaptic protein immunoreactivity and spatial memory in female mice. Proc Natl Acad Sci U S A 101:2185-2190. CrossRef Medline

Lin Y, Bloodgood BL, Hauser JL, Lapan AD, Koon AC, Kim TK, Hu LS, Malik AN, Greenberg ME (2008) Activity-dependent regulation of inhibitory synapse development by Npas4. Nature 455:1198-1204. CrossRef Medline

Lindberg MK, Weihua Z, Andersson N, Movérare S, Gao H, Vidal O, Erlandsson M, Windahl S, Andersson G, Lubahn DB, Carlsten H, Dahlman-Wright K, Gustafsson JA, Ohlsson C (2002) Estrogen receptor specificity for the effects of estrogen in ovariectomized mice. J Endocrinol 174:167-178. CrossRef Medline

Lindberg MK, Moverare S, Skrtic S, Gao H, Dahlman-Wright K, Gustafsson JA, Ohlsson C (2003) Estrogen receptor (ER)- $\beta$ reduces ER $\alpha$-regulated gene transcription, supporting a "ying yang" relationship between ER $\alpha$ and ER $\beta$ in mice. Mol Endocrinol (Baltimore) 17:203-208. CrossRef Medline

Liu F, Day M, Muñiz LC, Bitran D, Arias R, Revilla-Sanchez R, Grauer S, Zhang G, Kelley C, Pulito V, Sung A, Mervis RF, Navarra R, Hirst WD, Reinhart PH, Marquis KL, Moss SJ, Pangalos MN, Brandon NJ (2008) Activation of estrogen receptor- $\beta$ regulates hippocampal synaptic plasticity and improves memory. Nat Neurosci 11:334-343. CrossRef Medline 
Lubahn DB, Moyer JS, Golding TS, Couse JF, Korach KS, Smithies O (1993) Alteration of reproductive function but not prenatal sexual development after insertional disruption of the mouse estrogen receptor gene. Proc Natl Acad Sci U S A 90:11162-11166. CrossRef Medline

Markham JA, Pych JC, Juraska JM (2002) Ovarian hormone replacement to aged ovariectomized female rats benefits acquisition of the Morris water maze. Horm Behav 42:284-293. CrossRef Medline

Markowska AL, Savonenko AV (2002) Effectiveness of estrogen replacement in restoration of cognitive function after long-term estrogen withdrawal in aging rats. J Neurosci 22:10985-10995. Medline

Mehra RD, Sharma K, Nyakas C, Vij U (2005) Estrogen receptor $\alpha$ and $\beta$ immunoreactive neurons in normal adult and aged female rat hippocampus: a qualitative and quantitative study. Brain Res 1056:22-35. CrossRef Medline

Nilsen J, Diaz Brinton R (2003) Mechanism of estrogen-mediated neuroprotection: regulation of mitochondrial calcium and Bcl-2 expression. Proc Natl Acad Sci U S A 100:2842-2847. CrossRef Medline

Nilsson S, Mäkelä S, Treuter E, Tujague M, Thomsen J, Andersson G, Enmark E, Pettersson K, Warner M, Gustafsson JA (2001) Mechanisms of estrogen action. Physiol Rev 81:1535-1565. Medline

Noppens RR, Kofler J, Hurn PD, Traystman RJ (2005) Dose-dependent neuroprotection by $17 \beta$-estradiol after cardiac arrest and cardiopulmonary resuscitation. Crit Care Med 33:1595-1602. CrossRef Medline

O’Lone R, Knorr K, Jaffe IZ, Schaffer ME, Martini PG, Karas RH, Bienkowska J, Mendelsohn ME, Hansen U (2007) Estrogen receptors $\alpha$ and $\beta$ mediate distinct pathways of vascular gene expression, including genes involved in mitochondrial electron transport and generation of reactive oxygen species. Mol Endocrinol (Baltimore) 21:1281-1296. CrossRef Medline

Olsen L, Rasmussen HB, Hansen T, Bagger YZ, Tankó LB, Qin G, Christiansen C, Werge T (2006) Estrogen receptor $\alpha$ and risk for cognitive impairment in postmenopausal women. Psychiatr Genet 16:85-88. CrossRef Medline

Paruthiyil S, Cvoro A, Tagliaferri M, Cohen I, Shtivelman E, Leitman DC (2011) Estrogen receptor $\beta$ causes a G2 cell cycle arrest by inhibiting CDK1 activity through the regulation of cyclin B1, GADD45A, and BTG2. Breast Cancer Res Treat. 129:777-784. CrossRef Medline

Pettersson K, Delaunay F, Gustafsson JA (2000) Estrogen receptor $\beta$ acts as a dominant regulator of estrogen signaling. Oncogene 19:4970-4978. CrossRef Medline

Prange-Kiel J, Wehrenberg U, Jarry H, Rune GM (2003) Para/autocrine regulation of estrogen receptors in hippocampal neurons. Hippocampus 13:226-234. CrossRef Medline

Priest CA, Eckersell CB, Micevych PE (1995) Estrogen regulates preproenkephalin-A mRNA levels in the rat ventromedial nucleus: temporal and cellular aspects. Brain Res Mol Brain Res 28:251-262. CrossRef Medline

Quintela T, Gonçalves I, Baltazar G, Alves CH, Saraiva MJ, Santos CR (2009) $17 \beta$-Estradiol induces transthyretin expression in murine choroid plexus via an oestrogen receptor dependent pathway. Cell Mol Neurobiol 29: 475-483. CrossRef Medline

Rissman EF, Heck AL, Leonard JE, Shupnik MA, Gustafsson JA (2002) Disruption of estrogen receptor $\beta$ gene impairs spatial learning in female mice. Proc Natl Acad Sci U S A 99:3996-4001. CrossRef Medline

Rune GM, Frotscher M (2005) Neurosteroid synthesis in the hippocampus: role in synaptic plasticity. Neuroscience 136:833-842. CrossRef Medline

Semple-Rowland SL, Eccles KS, Humberstone EJ (2007) Targeted expression of two proteins in neural retina using self-inactivating, insulated lentiviral vectors carrying two internal independent promoters. Mol Vis 13:2001-2011. Medline

Sharma PK, Thakur MK (2006) Expression of estrogen receptor (ER) $\alpha$ and $\beta$ in mouse cerebral cortex: effect of age, sex and gonadal steroids. Neurobiol Aging 27:880-887. CrossRef Medline

Sherwin BB (2006) Estrogen and cognitive aging in women. Neuroscience 138:1021-1026. CrossRef Medline

Shim GJ, Wang L, Andersson S, Nagy N, Kis LL, Zhang Q, Mäkelä S, Warner M, Gustafsson JA (2003) Disruption of the estrogen receptor $\beta$ gene in mice causes myeloproliferative disease resembling chronic myeloid leukemia with lymphoid blast crisis. Proc Natl Acad Sci U S A 100:6694-6699. CrossRef Medline

Sohrabji F, Miranda RC, Toran-Allerand CD (1994) Estrogen differentially regulates estrogen and nerve growth factor receptor mRNAs in adult sensory neurons. J Neurosci 14:459-471. Medline

Sohrabji F, Miranda RC, Toran-Allerand CD (1995) Identification of a putative estrogen response element in the gene encoding brain-derived neurotrophic factor. Proc Natl Acad Sci U S A 92:11110-11114. CrossRef Medline

Talboom JS, Williams BJ, Baxley ER, West SG, Bimonte-Nelson HA (2008) Higher levels of estradiol replacement correlate with better spatial memory in surgically menopausal young and middle-aged rats. Neurobiol Learn Mem 90:155-163. CrossRef Medline

Tang YP, Haslam SZ, Conrad SE, Sisk CL (2004) Estrogen increases brain expression of the mRNA encoding transthyretin, an amyloid $\beta$ scavenger protein. J Alzheimers Dis 6:413-420; discussion 443-449. Medline

Thakur MK, Sharma PK (2007) Transcription of estrogen receptor $\alpha$ and $\beta$ in mouse cerebral cortex: effect of age, sex, $17 \beta$-estradiol and testosterone. Neurochem Int 50:314-321. CrossRef Medline

Tohgi H, Utsugisawa K, Yamagata M, Yoshimura M (1995) Effects of age on messenger RNA expression of glucocorticoid, thyroid hormone, androgen, and estrogen receptors in postmortem human hippocampus. Brain Res 700:245-253. CrossRef Medline

Too CK, Giles A, Wilkinson M (1999) Estrogen stimulates expression of adenine nucleotide translocator ANT1 messenger RNA in female rat hearts. Mol Cell Endocrinol 150:161-167. CrossRef Medline

Tremblay GB, Tremblay A, Copeland NG, Gilbert DJ, Jenkins NA, Labrie F, Giguere V (1997) Cloning, chromosomal localization, and functional analysis of the murine estrogen receptor $\beta$. Mol Endocrinol (Baltimore) 11:353-365. CrossRef Medline

Walf AA, Koonce CJ, Frye CA (2008) Estradiol or diarylpropionitrile administration to wild type, but not estrogen receptor $\beta$ knockout, mice enhances performance in the object recognition and object placement tasks. Neurobiol Learn Mem 89:513-521. CrossRef Medline

Walf AA, Koonce C, Manley K, Frye CA (2009) Proestrous compared with diestrous wild-type, but not estrogen receptor $\beta$ knockout, mice have better performance in the spontaneous alternation and object recognition tasks and reduced anxiety-like behavior in the elevated plus and mirror maze. Behav Brain Res 196:254-260. CrossRef Medline

Wang L, Andersson S, Warner M, Gustafsson JA (2001) Morphological abnormalities in the brains of estrogen receptor $\beta$ knockout mice. Proc Natl Acad Sci U S A 98:2792-2796. CrossRef Medline

Williams C, Edvardsson K, Lewandowski SA, Ström A, Gustafsson JA (2008) A genome-wide study of the repressive effects of estrogen receptor $\beta$ on estrogen receptor $\alpha$ signaling in breast cancer cells. Oncogene 27:1019-1032. CrossRef Medline

Windahl SH, Hollberg K, Vidal O, Gustafsson JA, Ohlsson C, Andersson G (2001) Female estrogen receptor $\beta^{-1-}$ mice are partially protected against age-related trabecular bone loss. J Bone Miner Res 16:1388-1398. CrossRef Medline

Woo JM, Park SJ, Kang HI, Kim BG, Shim SB, Jee SW, Lee SH, Sin JS, Bae CJ, Jang MK, Cho C, Hwang DY, Kim CK (2010) Characterization of changes in global gene expression in the brain of neuron-specific enolase/ human Tau23 transgenic mice in response to overexpression of Tau protein. Int J Mol Med 25:667-675. CrossRef Medline

Woolley CS, McEwen BS (1992) Estradiol mediates fluctuation in hippocampal synapse density during the estrous cycle in the adult rat. J Neurosci 12:2549-2554. Medline

Woolley CS, McEwen BS (1993) Roles of estradiol and progesterone in regulation of hippocampal dendritic spine density during the estrous cycle in the rat. J Comp Neurol 336:293-306. CrossRef Medline

Woolley CS, Gould E, Frankfurt M, McEwen BS (1990) Naturally occurring fluctuation in dendritic spine density on adult hippocampal pyramidal neurons. J Neurosci 10:4035-4039. Medline

$\mathrm{Xu} \mathrm{X}$, Zhang Z (2006) Effects of estradiol benzoate on learning-memory behavior and synaptic structure in ovariectomized mice. Life Sci 79:15531560. CrossRef Medline

Yaffe K, Lindquist K, Sen S, Cauley J, Ferrell R, Penninx B, Harris T, Li R, Cummings SR (2009) Estrogen receptor genotype and risk of cognitive impairment in elders: findings from the Health $\mathrm{ABC}$ study. Neurobiol Aging 30:607-614. CrossRef Medline

Yang SH, Sarkar SN, Liu R, Perez EJ, Wang X, Wen Y, Yan LJ, Simpkins JW (2009) Estrogen receptor $\beta$ as a mitochondrial vulnerability factor. J Biol Chem 284:9540-9548. CrossRef Medline

Zeier Z, Kumar A, Bodhinathan K, Feller JA, Foster TC, Bloom DC (2009) 
Fragile X mental retardation protein replacement restores hippocampal synaptic function in a mouse model of fragile $\mathrm{X}$ syndrome. Gene Ther 16:1122-1129. CrossRef Medline 